\title{
Pamuk Prenses ve Yedi Cüceler Masalının Üç Hali: Grimm Kardeşler, Walt Disney Ve Ertem Göreç
}

\author{
Zeynep Gültekin Akçay (Dr. Öğr. Üyesi) \\ Sivas Cumhuriyet Üniversitesi İletişim Fakültesi \\ zga@cumhuriyet.edu.tr
}

Başvuru Tarihi: 24.04.2020

Yayına Kabul Tarihi: 30.05.2020

Yayınlanma Tarihi: 24.07.2020

https://doi.org/10.17680/erciyesiletisim.726217

\section{Öz}

Sözlü kültür ürünü olan masalların kuşaktan kuşağa aktarılmasında yeniden üretim biçimleri önemlidir. Yeniden üretim sırasında masallarda yapısal, ideolojik değişikliklerin yaşanması kaçınılmazdır. Bu değişikliklerin bariz şekilde hissedildiği masal örneklerinden biri de Pamuk Prenses ve Yedi Cüceler'dir. Çalışmanın konusunu, Pamuk Prenses ve Yedi Cüceler masalının yeniden üretim biçimi oluşturmaktadır. Pamuk Prenses ve Yedi Cüceler masalının yeniden üretiminde, ne tür değişiklerin yapıldığı ve bunların hangi ideolojik, ekonomik ve kültürel kaygılarla yapıldığını ortaya koymak çalışmanın sorunsalıdır. Bu sorunsal ışığında, ilk önce masalın, 1812 yılında Alman Grimm Kardeşler tarafından yazılı eser haline getirilmesine değinilmiş, ikinci olarak 1937'de Disney'in, Grimmler'in masalının çizgi film uyarlaması ve son olarak da Disney'in çizgi filminden 1970'de Ertem Göreç'in uyarlaması ele alınmıştır. Sonuçta ise, Pamuk Prenses ve Yedi Cüceler masalının sözlü anlatıdan yazılı anlatıya, animasyon anlatısına ve sinema film anlatısına her üretildiğinde, ideolojik kaygılarla yapısal değişiklikler yaşamış olduğunu söylemek mümkündür.

Anahtar Kelimeler: Pamuk Prenses ve Yedi Cüceler Filmi, Grimm Kardeșler Masalı, Walt Disney çizgi filmi, Ertem Göreç. 


\title{
Three Forms of the (Fair Tale of) "Snow White and the Seven Dwarfs": Brothers Grimm, Walt Disney and Ertem Göreç
}

\author{
Zeynep Gültekin Akçay (Asst. Prof. Dr.) \\ Sivas Cumhuriyet University Faculty of Communication \\ zga@cumhuriyet.edu.tr
}

Date Received: 24.04 .2020

Date Accepted: 30.05 .2020

Date Published: 24.07.2020

https://doi.org/10.17680/erciyesiletisim.726217

\begin{abstract}
Reproduction forms are important in the transfer of tales from generation to generation, which are products of oral culture. Structural, ideological changes are inevitable in fairy tales during reproduction. One of the examples of fairy tales where these changes are clearly felt is Snow White and the Seven Dwarfs. The subject of the study is the reproduction of Snow White and the Seven Dwarfs. The purpose of the study is to reveal what kinds of changes were made in the reproduction of the Snow White and the Seven Dwarfs and what ideological, economic and cultural concerns they were made. In light of this problematic, three forms of this tale are examined. In the study, firstly, the fairy tale written by German Grimm Brother in 182, secondly the Disney's animation adaptation of Grimm's fairy tale in 1937, and finally the adaptation of Ertem Göreç from Disney's cartoon in 1970 were discussed. In conclusion, it is possible to say that the story of Snow White and the Seven Dwarves has been subjected to structural changes with ideological concerns every time it is produced from oral narrative to written narration, animation narration and cinema film narrative.
\end{abstract}

Keywords: Snow White and the Seven Dwarfs Movie, Grimm Brothers' Fairy, Walt Disney's animation, Ertem Göreç. 


\section{Giriş}

Toplumsal bir kültür ürünü olan sözlü anlatılar, ilk çıktıkları zamandan itibaren aktarımlar sırasında yeniden üretilerek günümüze kadar varlıklarını sürdürmüşlerdir. Sözlü gelenek içinde yer alan masallar, yeni anlatılara da kaynak ve malzeme olmuşladır. Masalların her yeni anlatıya kaynak olduğu durumda yeniden üretilmişlerdir. Masalların bu yeniden üretim sürecinde masallar, sözlü gelenek ve yazılı gelenek olarak iki biçimde günümüze kadar gelmiştir. Bu iki süreci Evrim Ölçer Özünel (2011, s. 61) şu şekilde anlatmaktadır: "Bunlardan biri halkın içinde 'kaba, saba ve naif' bir biçimde anlatılarak yaşayan 'sözlü' masal geleneğidir; diğeri de izleri günümüzde de görülebilen, eğitimli, okuryazar kesimin ilgisini çeken 'yazılı' gelenektir". Masalın yazıya geçirilme sürecinde sözlü anlatımlara istendiği gibi şekil verilmesi, esasında kolektif yaratımdan bireysel tasarıma geçiş için bir eşik olmuştur. "Belli bir kişinin kaleminden halk masalına eklenen herhangi bir unsur ve masalın altına atılan imza, onu halkın üretimi olmaktan çıkarıp tek bir kişinin yaratımı kılmıştır. Masallar, yazılı edebiyatın bir parçası haline geldikleri zaman, artık sınırları çizilmiş, kendilerini yazan bir yazar adı kazanmış, bir hedef kitlesi” (B. H. Yılmaz, 2013, s. 19) edinmişlerdir. Masallar hedef kitleleri, dilleri, içerikleri ve biçimleri değiştirilerek bir anlamda ardıl ürünlere dönüştürülmüş, yeniden üretilmiş bu sayede günümüze kadar küresel ölçekte varlığını sürdürmeyi başarmıştır.

Sözlü kültür ürünü olarak ortaya çıkmış olan Schneewittchen (Snow White and Seven Dwarfs- Pamuk Prenses ve Yedi Cüceler)'in yaklaşık 200 senedir farklı metin türleriyle toplumsal bir metin haline dönüşerek günümüze kadar geliş serüvenini değerlendirmek, bu metnin toplumsal tarih içindeki sürekliliğinin anlaşılmasına da olanak sağlayacaktır. Metin ilk önce Alman Grimm Kardeşler tarafından sözden yazıya aktarılmış, bu süreçte Grimm Kardeşler metinlere müdahalelerde bulunmuştur. Pamuk Prenses ve Yedi Cüceler (David Hand, Wilfred Jackson, Ben Sharpsteen, William Cottrell, Larry Morey, Perce Pearce) 1937 yılında Walt Disney tarafından çizgi filme uyarlandığında ise bir kez daha yeniden üretimin getirdiği değişikliklere maruz bırakılmıştır. Masal 1970 yılında ülkemize taşınmış Ertem Göreç tarafından Yeşilçam'a uyarlanarak Türk seyircisinin beğenisine sunulmuştur. Masalların yeniden üretiminde kahraman sayısından, mekân ve zaman kurgusuna, olay örgüsüne kadar geniş bir yelpazede değişiklik yaşandığı görünmektedir. $\mathrm{Bu}$ açıdan Pamuk Prenses ve Yedi Cüceler eserinin, kültürel üretim farklılıklarını, bu farklılıkların ne olduğunu, farklılıkların nedenlerinin temel unsurlarını ortaya koymak çalışmanın temel sorunsalıdır. Bu çaba ile masalın zaman, coğrafya ve türler arası taşınmalarının nedenlerinin neler olabileceği tartışılmaya çalışılacaktır. Metini, yazılı masal, animasyon ve sinema filmi gibi farklı metinlerle karşılaştırmak için metinlerarasılık önemli bir yol göstericidir. Pamuk Prenses ve Yedi Cüceler, ise Kristeva'nın metinlerarasılık tartışmasına uyan örneklerden birisidir. Üç farklı metin, Kristeva'nın (1980, ss. 72-73) Desire in Language A Semiotic Approach to Literature and Art, isimli kitabında bahsettiği, metinlerin değiş tokuş esnasındaki unsurlardan yola çıkarak incelenmiştir.

Pamuk Prenses ve Yedi Cüceler metinine, alıntılar mozaiği, önceki metinlerden izler taşıyan anonim formül olarak bakıldığında ortaya çıkmış olan metinlere eğilmek önemlidir. Metinler arasındaki değiş tokuşlarla birlikte her yeni metin, toplumsal tarih içindeki sürekliliğin anlaşılmasına olanak sağlamaktadır. Farklı metin türleriyle karşımıza çıkmış olan Pamuk Prenses ve Yedi Cüceler'i, farklı disiplinlerde pek çok araştırmacı incelenmiştir. Türkiye'de, metinin masal formuyla daha çok halkbilimciler ilgilenmişlerdir. Masalların insan toplulukları için kültürel gen haritaları gibi olduğuna değinen Evrim Ölçer Özünel (2011), masalların Doğu ve Batı'daki gelişim sürecini karşılaştırmalı örnekler vererek 
incelemiş̦tir. Çalışmasında, özellikle Grimm Kardeşlerin bu zincirdeki yeri sorgulanmıştır. Grimm masallarının sahte folklor yani 'fakelore' üretip üretmediği tartışılmış ve kardeşlerin sahte folklor üretmekten çok kendilerinden önceki masal yazma geleneğini takip ettiği saptanmıştır. Betül Havva Yılmaz'ın (2013) Çağdaş Türk Edebiyatında Grimm Masallarının Metinlerarası Kullanımları isimli yüksek lisans tezinde Murathan Mungan'ın romanları ve Grimm Masalları metinlerarasılık bağlamında incelenmiştir. Çalışmaya göre, anıştırma, gönderge, indirgeme, öykünme, yanılsama gibi kullanımlarla sözlü kültür ürünlerinin dönüşerek günümüze kadar geldiği belirtilmiştir. Masalları, rasyonalitesi gizlenmiş, süslenmiş ve metaforlarla örülmüş, sembollerle örtülmüş bir rasyonalite olarak gören bir çalışmada ise gizlenmiş olan bu rasyonaliteyi çıkarmak için psikanizin kullanımına işaret edilmiştir. Pamuk Preses ve Yedi Cüceler'e psikanalitik açıdan yaklaşan bu çalışmaya göre, metin egemen ataerkil ideolojiyi yeniden üretmektedir (Sarı \& Ercan, 2008).

Masal ve sinema ilişkisi üzerine ülkemizde pek çok çalışma yapılmış olmakla birlikte doğrudan Pamuk Preses ve Yedi Cüceler'le ilgili yapılmış çalışmaların sayısı azdır. 1812 yılında basılan masal metni ile 2012 yılında Hollywood tarafından çekilen Pamuk Prenses ve Avcı filmini metinlerarası bakış açısıyla inceleyen bir çalışmada benzerlik ve farklılıklar üzerine karşılaştırma yapılmıştır. Çalışma daha çok 2012 yapımına değinmiş, iki metin arasındaki benzerliklere dikkat çekilmiştir (Özcan Dost \& Taştan, 2017). Masalların, mitos, ritus ve arketiplerin tekrarlanması, aktarılması ve dönüşmesi yoluyla oluştuğunu belirten bir başka çalışmada Charles Perrault ve Grimm Kardeşler'in masallarının sinema uyarlamaları üzerine tartışılmıştır. Pamuk Prenses ve Yedi Cüceler bu çalışmaya doğrudan konu edilmese de kahramanın erginleșmesi, ensest, dondurulmuş motif (Tunalı, 2017) unsurları üzerinden uyarlamalara genel olarak değinilmiștir. Anlat İstanbul filmini Grimm Kardeşlerin masallarıyla ilişkilendirerek, ağ anlatı açısından inceleyen çalışmada ise film karakterlerinin yani masal kahramanlarının hepsinin toplumsal bir ağ oluşturduğuna değinilmektedir (Tuğan, 2017). Film Uyarlamalarında Anlatının Dönüşümü Yetişkinlere Masallar: Pamuk Prenses (Şakrak, 2017) başlıklı çalışmada, masalın Hollywood tarafından üç farklı uyarlaması Laura Mulvey'den yola çıkılarak incelenmektedir. Çalışmaya göre, çocuklar için yaratılmış masallar sinema filmleriyle yetişkinlere yönelik hale gelmişlerdir ve bu filmlerde egemen ataerkil kodların üretimi hiç bitmemektedir. Pek çok Yeşilçam değinisinde, Ertem Göreç'in 1970 yılındaki filmi Yeşilçam'da masal furyasını başlatan öncüller içinde anılmakla birlikte uyarlama açısından incelenmemiştir. Yapılan araștırma sonucunda Ertem Göreç ile ilgili çalışmaların yönetmenin diğer filmlerine ağırlık verdiğini söylemek mümkündür. Bu noktada, sadece Türk Sineması'nda Masal Uyarlamaları ve Vladimir Propp'un Halk Masalları İşlevlerinin Pamuk Prenses ve Yedi Cüceler Filminde Çözümlenmesi (Doğan, 2018)başlıklı çalışmayla karşılaşılmıştır. Bu çalışma ise Propp'un işlevlerinin filmdeki karşılığının araştırılması üzerinedir.

Pamuk Prenses ve Yedi Cüceler masalı ile ilgili Türkiye'de yapılan çalışmalarda edebiyat ve halkbilim disiplini açısından metnin yaratım değeri ele alınırken, Walt Disney'in Pamuk Prenses ve Yedi Cüceler'i üzerine pek çalışma yapılmadı̆̆ı bunun yanında daha çok Hollwood'un çeşitli uyarlamaları üzerine yoğunlaşıldığı gözlemlenmektedir. Yeşilçam'da ki Pamuk Prenses filmine ise daha çok masal furyasının başlamasına neden olan ilk film olarak pek çok çalışmada bir iki cümleyle değinilmiş; ancak Disney'in çizgi film uyarlaması olarak ele alınıp detaylı olarak incelenmemiştir. Bu noktada çalışma, sözlü kültür ürünü olan masalın yeniden üretim biçimlerindeki farklılıkları yazılı eser, çizgi film ve yerli film uyarlamasıyla ilişkilendirerek, yukarıda söz edilen araştırmalardan ayrılabilmeyi, masalın yeniden üretilme sürecinin anlaşılmasına bir katkı sunabilmeyi ummaktadır. 


\section{Bir Yöntem Olarak Metinlerarasılık}

Sözlü kültür ürünü olarak ortaya çıkmış olan Pamuk Prenses ve Yedi Cüceler'in yaklaşık 200 senedir farklı metin türleriyle toplumsal bir metin haline dönüşerek günümüze kadar geliş serüvenini değerlendirmek, bu metnin toplumsal tarih içindeki sürekliliğinin anlaşılmasına da olanak sağlamaktadır. Bu sözlü kültür ürününü, yazılı masal, animasyon ve sinema filmi gibi farklı metinlerle karşılaştırmak için metinlerarasılık önemli bir yol göstericidir. Metinlerarasılık, Mikhail Bakhtin'in diyalojizm (söyleşimcilik) teriminden yola çıkarak Julia Kristeva tarafından kullanılmıștır. Bakhtinci diyalojizm, yazmayı hem öznellik hem de iletişim olarak tanımlamaktadır. Diyolojizmle yüzleşildiğinde, yazıya konu olan kişi kavramı bulanıklaşır ve onun yerine yazım kararsızlığı gelir. Bu nedenle hiçbir metin aslında özgün değildir (Kristeva, 1980, s. 68). Robert Stam (2000, s. 64) kültürel yaşamı, metne dönüștüren hem birincil (sözlü) hem de ikincil (edebi) türlerden oluşan sosyal yaşam ve tarihe dayanan karmaşık ve çok boyutlu diyalojizmden bahsetmektedir. Metinlerarası bu diyalojizmi, bir kültürün tüm söylemsel uygulamaları tarafından oluşturulan sonsuz ve açık uçlu olasılıklar, sanatsal metnin içinde yer aldığı iletişim metninin tüm matrisi, sadece tanınabilir etkilerle metne ulaşan, aynı zamanda ince bir yayma süreci olarak tanımlamaktadır. Julia Kristeva'ya göre (1980, ss. 36, 117, 215) metin bir üretkenliktir. Yeniden üretim ile öznellikten bahsedilemese de semptomatik olan ideoloji gözden kaçırılmamalıdır. Bu ideoloji ise normu, antinormu, yasakları, aşırılığı ve bastırılmışlığı işaret eder. Bu nedenle de toplumsal mücadele, kültürel değerler ve kırılmaları barındırır. Tüm metinler, anonim formüllerin dokuları, bu formüllerin varyasyonları, bilinçli ve bilinçsiz alıntılar ve diğer metinlerin birleşmeleri ve ters çevrimleridir (Stam, 2000, s. 64). Metnin, bulunduğu dille olan ilişkisi yıkıcı aynı zamanda da yapıcıdır. Metinlerin değiş tokuşu (apermutation) bir metinlerarasılıktır şöyle ki; belirli bir metinin, diğer metinlerden alınan çeşitli ifadeleri birbiriyle kesişir aynı zamanda da birbirlerini de nötralize ederler. Bu nedenle de her metin, bir alıntılar mozaiği, emilim ve geçmişteki metinlerden izler taşıyan bir dönüşümdür. Metinlerin birbirlerinden aldığı ifadelerle, kaynak ile bu kaynaktan yapılan uyarlamalar arasında bükülmeler olduğu gibi, kültürel tarihin doğrusal, tarihsel anlayışı da kökten zayıflayarak yeni bir süreç başlar (Aragay \& Lopez, 2005, s. 201).

Bir aracı olarak yazarlar, öncesi ve sonrası gibi hiyerarşileri es geçen bir diyalojidir. $\mathrm{Bu}$ nedenle de tüm metinler birbirleriyle ilişkilerini sürdürürler. Yazarlar bağlamları ve metinleri kendi yaratılıș hareketlerinde yeniden üretirler. $\mathrm{Bu}$ durumda, metni oluşturanlar, içinde bulundukları dönemdeki veya öncesindeki yaratılmış olan metinlerden yararlanarak kendi metinlerini oluştururlar. Bu durumda da, "Roland Barthes'in 'yazarın ölümü' ilanının aksine, Kristeva için bir metinin yeni metinlerle girdiği ilişki, aslında diyalojiye girilen bir kanaldır ve sayısız kaynakla girilen diyaloji nedeniyle metin bir alıntılar örüntüsüdür" (Aragay \& Lopez, 2005, s. 202). Metinler arasındaki değiştokuşla birlikte, tüm bağlamlar eşit öneme sahip olurlar. Bir metnin uyarlanarak yeniden üretilmesi -çok daha fazla insanın izlemesi, okuması vb.- sayesinde metnin sosyal etkisi de fark edilecektir. Ancak bu fark ediliş sürecinde metinlerin yeniden üretim bağlamlarına değinilmesi önemlidir çünkü metinler artık zaman ve coğrafya açısından kökensizdirler (Desmond \& Hawkes, 2006, s. 46).

Pamuk Prenses ve Yedi Cüceler, Kristeva'nın metinlerarasılık tartışmasına uyan örneklerden birisidir. Her bir metin bir öncekini kullanıp ona göndermeler yaparken bir yandan da kendi unsurlarını kurmaktadır. Sözlü kültür ürünü olarak Almanya'da ortaya çıkmasından hemen sonra, Alman Grimm Kardeşler tarafından 1812'de yazıya aktarılması, 1937'de bu 
metnin Amerika'ya taşınması ve 1970'de ülkemize gelmesi çarpıcıdır. Yine Kristeva'nın belirttiği gibi bu metinler bir yandan yararlandığı önceki metinleri yıkarken, bir yandan da yeniden üretilmektedir. Çalışmaya konu edilen metinlerin, bir önceki metinden faydalanarak aynı unsurları kullandığını söylemek mümkünken ayrıldığı (olay örgüsü, kahramanları, mekan ve zaman kurgusu) pek çok noktanın olduğundan bahsetmek mümkündür. Pamuk Prenses ve Yedi Cüceler'in değișimi nasıl olmuștur? Bu değișimin etkileyen nedenler nelerdir? Metinler arasındaki ilişkiler ve buna bağlı farklılıklar nelerdir? soruları ise Kristeva'nın (1980, ss. 72-73) Desire in Language A Semiotic Approach to Literature and Art, isimli kitabının 'Classification of Words Within The Narrative' başlıklı yazısında ele aldığı, metinlerin değiş tokuş esnasındaki unsurlardan yola çıkarak yanıtlanmaya çalışılacaktır. Bu unsurlar kısaca alıntı, gizli alıntı, anıştırma pastiş, parodidir. Alıntı, kaynak metinden alınanın bir başka metinde varlığının doğrudan hissedilmesidir. Bu sayede de metni kullananlara kullanılan metinle ilgili bilinçli bir hatırlatma yapılır. Gizli alıntı ise, kaynak metinden aşırıya varacak şekilde alıntı yapması, metni yeniden üretenin kendi fikriymiş gibi hissettirmesidir. Anıştırma ise, alıntının dolaylı kullanımıdır. Bir metnin biçimi değiştirilmeden konusu değiștirildiğinde bu sayede de yeni anlam yaratıldığında Parodiden bahsetmek mümkündür. Bireysel öznenin kaybolması ve kişisel biçemin giderek varlığını yitirmesi ise pastiştir. Bu durumda Pamuk Prenses ve Yedi Cüceler'in belirtilen farklı dönemlerdeki farklı metinlerini, bu farklılıkların ne olduğunu, farklılıkların nedenlerinin temel unsurlarını ortaya koymak çalışmanın temel sorunsalıdır. Bu çaba ile masalın zaman, coğrafya ve türler arası taşınmalarının nedenleri tartışılmaya çalışılacaktır.

\section{Masalın Yolculuğu}

Sözlü gelenek döneminde insanların çeşitli nedenlerle hikaye anlatma ihtiyacını karşılamak için ortaya çıkan masallar nesilden nesile aktarılmıştır. Sözlü edebiyat geleneği içinde kabul edilen masallar günümüze kadar çeşitli medya biçimlerince yeniden üretilerek de yüzyıllardır varlığını sürdürmüștür. Her ne kadar masallar sözlü edebiyat içerisinde tanımlansa da günümüze kadar gelmesinde yazı önemli bir araç olmuştur. Masal yazıya aktarılırken yapısal ve ideolojik değişiklikler yaşamakla birlikte yazılı edebiyatta da bir tür oluşturmuştur (Çakır, 2017, s. 136). Böylece masal, hem yazılı edebiyatta hem de sözlü gelenekte varlığını korumuş bunun yanında multimedya ortamlarında da varlığını sürdürerek ve günümüze kadar gelmiştir.

Masal ile ilgili çalışmalar iki koldan ilerlemektedir. Bir görüşe göre masallar, iyimserlikleriyle çocuklar üzerinde kurtarıcı etkiye sahiptir (Kaminski, 2016). Bununla birlikte masallar, "insanları erdem, ahlâk, toplumsal cinsiyet rolleri gibi normatif kurallar konusunda eğitebilecek eğlenceli bir oyuncak ve zengin bir araç olarak" (Ölçer Özünel, 2011) görülmüştür. Masallar hakkında çalışmalar yapan Bruno Bettelheim (Bettelheim, 2010, ss. 52-66), Ezop'un fabllarına göre masalların, çocuklar üzerinde çok olumlu etkiler yaptığından bahsetmektedir. Masallar çocukların gerçek dünyayı anlamlandırmasında yetişkinlerin verdiği yanıtlardan çok daha yol göstericidirler. Masallar, gerçek ile bilinmeyen arasında köprüdürler. Aynı zamanda, çocukların karşılaştığı sorunların doğasına dair çözüm önerileri sunarak onlara düş dünyası ile gerçek dünya arasında bir geçiş de sağlarlar. Masalların çocukların üzerinde kurtarıcı etkiye sahip olduğunu söyleyen Bettelheim'ın tam tersini ifade eden çalışmalar da söz konusudur. Bunlara göre, masal ideolojiktir ve dönemin ideolojisini yerleştirmek için üretilmiştir. Bunlardan Christina Bacchilega'ya (Bacchilega, 1997) göre, masal, sıklıkla burjuvazinin veya muhafazakârların çıkarlarını desteklemek için araçsallaştırılmıştır. Masalların, aslında 
prekapitalist insanların daha iyi yaşam koşullarını elde etmek için onların isteklerini anlatan sözlü gelenekler olduğunu belirten Jack Zipes'e (1975) göre ise, masallar, basılı hâle geldiklerinde sterilize edilmişlerdir. Prekapitalist zamanda halk masallarında sınıf çatışmaları, isyan gibi yaratıcı motif ve sembolik unsurlar söz konusudur. Sözlü kültür ürünü olan masallar burjuva sınıfının ortaya çıkmasından sonra bu sınıfın yarattığı rasyonalite ve faydacılıkla çatışmıştır ${ }^{1}$.

On sekizinci ve on dokuzuncu yüzyıllarda, insanların eğitilmesi ve okuma yazmayı öğrenmeleri gerektiğine inanılmış, bu durum içeriklerin kontrol edilmesi ile yapılmıştır. Kontroller ya da sansürler tüm edebî formlar için geçerli olmuştur. Zipes (1975) masallar için iki tür kontrol/sansürden bahsetmektedir: İlki, masal anlatıcılarının masallarının basılmamasıdır. Bununla birlikte masalları stilize etmiş olan derleyicilerin masallarının basılması da birinci tür kontrol içinde sayılmaktadır. Bu derleyicilerin masalları, kolektif bilinci eğitmek çoğu kez de ıslah etmek ve bireyleri kurulu toplumsal düzeni kurallarına davet etmek amacıyla (Köse, 2014, s. 12) yaratılmışlardır. İkinci kontrol/sansür ise, gazetelere, dergilere masallar yerine burjuva ahlâkını yayan didaktik hikâyelerin basılması bu sayede de haksızlıkların anlatıldığı isyankâr öykülerin kolektif hafızadan silinmeye çalışılmasıdır. Bu nedenle basılı masalların 'gerçek' tarihi ve toplumsal ilişkileri bozduğunu belirten Jack Zipes'e (Zipes, 1975) göre masallar, tarihsel ardalanıyla yeniden okunmalıdır. Bu sayede masalların aslında krallıklardaki iktidar mücadelelerini meşrulaştırılan kuralları, parayı, toplumsal cinsiyet kodlarını üreten bir sistem ürünü olduğunu görmek mümkün olmaktadır. Masalların günümüze kadar gelmesinde yazılı kültür ürününe dönüşmesi kuşkusuz önemlidir. Masalların yazılı hâle geçirilmesine katkıda bulunan derleyicilerden Charles Perraut (1628-1703), Hans Christian Anderson (1805-1875) gibi isimlerden biri de Jacob-Wilhem Grimm (1785-1863) kardeşlerdir.

\section{Masalların Ilk Değişimi: Grimm Kardeşler}

Grimm masalları, soyadlarıyla anılan Wilhem ve Jakob kardeşler tarafından 1812 ve 1815 yıllarında iki cilt olarak basılan masal külliyatıdır. Külliyatın esas ismi Çocuk ve Yuva Masalları (Kinder und Hausmärchen) anlamına gelmektedir ancak dünyada Grimm Masalları olarak ünlenmiştir.

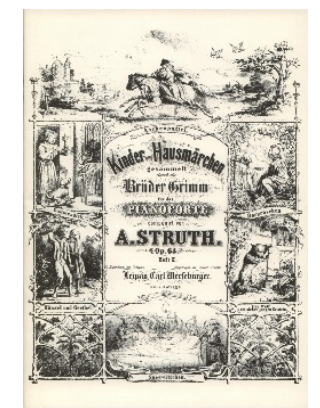

Görsel 1: Çocuk ve Yuva Masalları kitabının görseli

Kaynak: (https://merseburger.de/2020)

Yazılı masalların sözlü masallarda değișiklik yaptığını belirten Zipes’e göre (Zipes, 1975) göre, Grimm kardeşler sözlü halk hikâyelerini masal olarak yazıya dökerken değiştirmiş, dönemin şartlarına uyarlamış ve bunları burjuvalaştırmışlardır². Metinlerarasılığın, alıntı unsurunu Grimm Kardeşler kaçınılmaz olarak uygulamışlardır. Ursula Ewig'e (Ewîg, 1990) göre, ilk baskılardaki masallarla elyazması orijinalleri arasında farklılıklar görülmektedir. Elyazmasında sadece küçük notlar varken, ilk baskıda daha düzenlenmiş bir anlatım bulunmaktadır. Grimm Kardeşler, her baskıda eklemeler yaparak detaylara 
biraz daha ağırlık vermişlerdir. Bu katkılarla da 1812'deki ilk ciltte yer alan seksen altı masalın sayısı iki yüzü bulmuştur. Grimm Kardeşler, eserin ön sözünde, masalların sözlü kültür formlarında hiçbir değişiklik yapmadığını dile getirseler de, Alan Dundes'e göre (Dundes, 2006) yazarlar bu konuda pek de doğru söylememektedirler. Grimm Kardeșler, hem sözlü kültür ürünü olan hikayeleri (olayları, karakterleri ve hatta mekanları), hem de derledikleri kişilerin kimlik bilgilerini değiştirmişlerdir. Grimm Kardeşlerin masallarını ideal bir anlatıcıdan derledikleri iddiasının doğru olmadığını belirten Ölçer Özünel'e (Ölçer Özünel, 2011, s. 69) göre ise "anlatıcl, orta sınıftan okuma yazma bilen, eğitimli ana dili Almanca yerine, Fransızca olan biri” dir.

Grimm Kardeșlerin, dönemin değerlerinin yaygınlaşmasına önemli katkılar sunduğundan bahsetmek mümkündür. Sözgelimi masal karakterlerinin hâl ve hareketleri, dönemin ahlâkçılığı, burjuva etiği ve sosyal kültürel yaşamın öteki egemen belirleyici unsurlarından fazlasıyla nasibini almıștır. Jack Zipes (Zipes, 2006) Pamuk Prenses ve Yedi Cüceler masalında bu durumun izlerinin görülebileceğinden bahsetmektedir: Masalın 1812 yılındaki baskısında, kadının konumunun aslında burjuva sınıfı kadınının görevleriyle örtüştürüldüğüne değinmektedir. Bu dönemde büyüyen proleterya sınıfında yer alan kadın ve çocuklar daha çok fabrikalarda yani dışarıda olmak zorundayken Grimm kardeşlerin masalının çizmiş olduğu resimde burjuva sınıfının yaşam tarzına uygun olacak şekilde kadın, korunaklı ev alanı içerisinde konumlandırılmıştır. Bahsedilen dönemde yoksulların okuma yazma oranının burjuva sınıfına oranla düşük seviyede olması hikâyelerin daha çok burjuva sınıfının beklentilerine göre yazıldığını da ortaya çıkarmaktadır. Dolayısıyla Zipes'in (1975) de belirttiği gibi, Grimm kardeşlerin yazıya aktardığı masallar için feodal sistemden kopuşu simgeleyen on dokuzuncu yüzyıl temel burjuva normlarını, değerlerini, güç ilişkililerini içselleștirmeye ön ayak olan bir sosyalizasyon sürecidir demek yanlış olmayacaktır.

\section{Edebiyat ve Sinemanın Dayanılmaz İlişkisi}

Sinema, kendini anlatısal bir eğlence aracı olarak sunmasından bu yana kaynak metin olarak çoğunlukla edebî eserleri kullanmıştır. Sinema ve edebiyat arasındaki etkileşime farklı yorumlar getirilmiştir. Andre Bazin'e (1995) göre sinemanın edebiyata başvurmasını kabullenmek ve anlamaya çalışmak gerekir. Sinemanın edebiyata başvurma nedeni ise bir yandan edebiyatın konu birikiminden yararlanma arzusu diğer yandan da izleyicinin de bu konuları sinemada izleme isteğidir. Sinemanın edebiyatın birikimini kullanarak ürettiği uyarlamalar aslında edebiyata da hizmet eder. Pierre Bourdieu'ya (Bourdieu, 2006) göre edebiyat, sinemayı daha fazla satmak ve yeni basımlar için sermaye sağlamak adına kullanır ${ }^{3}$. Bununla birlikte, "filmler sayesinde sinemaya uyarlanan edebî eserlerin yeni basımlarının yapıldığı, satışlarının arttığı ve uyarlamayı izleyen ya da izlemeyen kişiler tarafından merak edilerek -en azından film gösterimde kaldığı dönemde- daha fazla okunduğu bir gerçektir" (Barut, 2007, s. 19). James Monaco'ya (Monaco, 2011) göre ise hem filmler hem de edebî eserler çok ayrıntılı uzun öyküler anlattıkları için birbirlerinden ayrı düşünülemezler. Edebî eserler de sinema da gerekli gördükçe birbirlerinin olanaklarından yararlanmaktadır. Ancak karşılıklı alınabilen unsurların, her iki sanat yönünden de tür niteliğini belirleyici temel öğeler olamayacağı açıktır (Aykın, 1983, s. 500). Sinema edebî türlerde gereksinimlerine uygun bütün ayrıntılarıyla ilginç konular, öyküler ve birtakım anlatım teknikleri bulmakta; edebi türler ise özellikle sinemanın somutlamada, görselleştirmede yararlı birtakım betimleme ve bileşim tekniklerine ilgi göstermektedir. 
Sinemanın edebî eserlere başvurma nedenlerinin genellikle sanatsal kaygllar ve bunun tam tersi ticari kaygılar olduğunu görmek mümkündür. Sanatsal kaygılar, özellikle güçlü metinler söz konusu olduğunda ortaya çıkar. Öykünün ilginç, yapının güçlü, karakterlerin derinlikli olması ve bunların da özelliklerini kaybetmeden perdeye aktarılabilmesi durumunda sanatsal değeri yüksek bir filmin oluşturulması sağlanabilir. Ticari olarak da edebî eserin geniş izleyici kitlesi çekeceği düşüncesidir. Eseri bilmeyenlerin onun ne olduğunu, bilenlerin ise ortaya ne çıktığını görmeye gidecekleri bu sayede de orijinal eserden alınan hazzın yeniden canlandırılacağı umudu (Çetin-Erus, 2005, s. 19) söz konusudur.

\section{Masalın İkinci Değişimi: Disney’in Sihirli Dünyası}

Hollywood sinemasında "film üretiminin temel amacı izlenirliktir yani türü ne olursa olsun bir film başkaları tarafından izlensin diye çekilmektedir. Bu durumda daha fazla sayıda izleyiciye ulaşmak film üretiminin temel amacıdır. Sinemada akılcılaștırmanın devreye girdiği nokta da budur. Verimliliğin arttırılması için üretim standart hale getirilmiş ve böylece maliyetler" (Şeşen, 2008, s. 85) düşürülmüştür. Bu sebeple ${ }^{4}$ Hollywood sineması ilk döneminden itibaren edebî eserleri uyarlama yoluna gitmiştir.

Hollywood stüdyosu olan Disney de bu uyarlama sürecinden payına düşeni almıștır. 16 Ekim 1923 tarihinde Walt ve Roy Disney kardeşler tarafından Disney animasyon stüdyosu kurulmuştur. İlk beş yıl, yaratılan çeşitli çizgi karakterlerle pek bir yere varılamamış olsa da 1928>de Steamboat Willi Mickey Mouse (Walt Disney, Ub Iwerks) piyasaya sürülmüş ve yaratılan Mickey Mouse karakteri yankı uyandırmıştır. Disney stüdyosu, bu tarihten bir süre sonra ekonomik depresyonla uğraşmak zorunda kalmıştır. Disney'in hayalperest ve ilham verici çizgi filmleri bu depresyon döneminde bile stüdyonun gelişmesine ve kârlı bir iş hâline gelmesine yardımcı olmuştur. Disney, paranın çoğunu animasyonların kalitesini arttırmak için kullanmış bu sayede de çeşitli ödüller almıştır. Elde edilen kar, yeni çizgi filmlerin finansal kaynağı olmuştur. Fleischer Stüdyosu gibi çeşitli stüdyolar, Disney'in yaptığı bu ekonomik cambazlığı yapmaktan kaçınmış ve kendilerini korumaya çalışmıştır (Pallant, 2010). Disney, 1930'lardaki ekonomik krizle başa çıkabilmek için çarpıcı bir yenilik daha yapmıştır. Alman yazarlar Jacob ve Wilhem Grimm tarafından basılan Pamuk Prenses ve Yedi Cüceler masalını 1937'de uzun metrajlı çizgi film olarak çekmişlerdir (Inge, 2004).

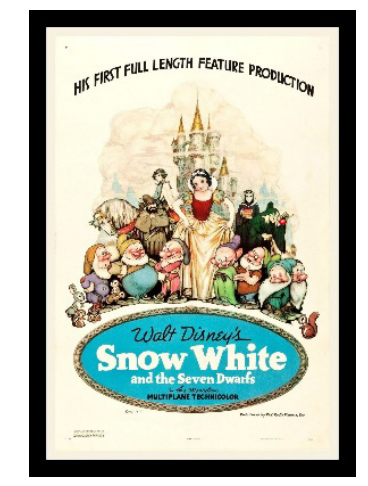

Görsel 2: Disney'in 1937'deki Pamuk Prenses ve Yedi Cüceler film afişi Kaynak: (https://www.ebay.com;2020)

Film, yayınlandıktan hemen sonra hâsılat rekorları kırmış ve tüm kıtalara satılmıștır (Bacchilega, 1997). Christina Moen'e (Moen, 2013) göre o dönemde Pamuk Prenses ve Yedi Cüceler'in Amerikan toplumu tarafindan bu kadar tutulmasının nedeni dönemin Time dergisinde şu şekilde açıklanmaktadır: "İzleyiciler, komedi, korku, müzikal gibi 
popüler filmlerin içine Pamuk Prenses'i de dâhil etmiştir çünkü film Western'den daha heyecanlı, komediden daha komiktir ve dahası film klasik drama ile çizgi roman mizahını birleştirmektedir. Disney'in bu kombinasyonu ise dönemin ekonomik depresyonuyla baş etmeye çalışan insanların fantezisini, üzüntüsünü bir araya getirmiştir". Amerika'da hasılat rekorları kıran bu film Atlantik'in diğer yakasında (Birleşik Krallık, Hollanda) korku ve şiddet unsurlarını barındırdığı için sansürlenmiş, içeriğinde değişiklikler yapılmış (Inge, 2004, s. 139) ve izleme şartı koyulmuştur. Filmin izlenebilmesi için seyircinin ya on yaşında olması ya da ebeveynleriyle izlemesi zorunluluğu getirilmiştir (Frome, 2013, s. 463).

Sözlü masalların basılı hâle gelmesinden sonraki bu değişikliği mutasyon ${ }^{5}$ olarak adlandıran Christina Moen'e göre (Moen, 2013, s. 176) günümüze kadar bu mutasyonu hızlandıran ve sürdüren tek isim Disney olmuştur. Disney, metinlerarasılık açısından parodiyi kullanara aslında Moen'in belirttiği dönüşüme de olanak sağlamıştır. Jack Zipes (Zipes, 2006, s. 196), masal türünün değişmesinde basılı sözcüklerin rol oynadığını belirtir ve ekler: "Türün kurumsallaşmasında bir sonraki devrim ise film teknolojisinin gelișimidir. Burada da sahneye Disney ve onun animatörleri çlkar"'. Disney'in tüm masal filmlerinde mükemmel, temiz ve düzenli bir dünya söz konusudur. Bunun nedeni ise Disney'in masalların isyankâr ve ilerici özelliklerinin yerine egemen ideolojileri yerleștirmesidir. Gilbert Adair'e göre (Adair, 1993, ss. 145-146) Disney'den sonra masallarla kurulan ilişki gerçek anlamıyla değişmiştir. Masalların hareketli hâle dönüşmesi Disney'le başlamış ve artık masalları hareketsiz ve yazılı formda düşünmek olanaksız bir duruma gelmiștir. Masalları toparlama ve yeniden yaratma iși Disney'e düşmüştür. Disney bu işi öylesine bir başarıyla yapmıştır ki; artık insanların Pamuk Prenses ve Yedi Cüceler, Pinocchio (Pinokyo, Hamilton Luske, Ben Sharpsteen, Norm Ferguson, Wilfred Jackson, Jack Kinney, T. Hee, Bill Roberts, 1940) veya Cinderella (Külkedisi Sindirella, Clyde Geronimi, Wilfred Jackson, Hamilton Luske, 1950) yı Disney'in yarattığı hareketli hayal dünyası olmadan akıllarına getirmesi imkânsızdır. Disney dünyasının yüze gülücü ve șematik kolaylı̆̆ı zamanla peri masallarının dünyasını aktarmak için en uygun araç hâline gelmiştir.

Amerika'da, hem dönemin sosyo-ekonomik koşullarının yarattığı kaygıları gözeten, hem de seyircinin beklentilerini bilen, Disney, Pamuk Prenses ve Yedi Cüceler çizgi filmi ile seyirci karşısına çıkmıştır. Disney, ekonomik buhran zamanı Amerikan ailelerinin bütçelerinden birazını filme aktarmaları konusunda onları ikna etmek için Grimm Masallarının anlatı yapısındaki bazı detayları değiștirmiş ve animasyon teknolojisinin sağladığı yenilikleri kullanmıştır. Bu sayede Disney, doksan dakika boyunca çocukların ve hatta onlarla birlikte ailelerinin de salonda oturmasını sağlamıştır (Inge, 2004, s. 138). Aynı zamanda, Disney, çizgi filme, dönemin Amerikan tutucu ideolojisini içeren belli anlatıları: Ahlâki değerlere biat, vatanseverlik, bireycilik, kapitalizm, çalışma ahlâkına sıkı sıkıya bağlılık, aile kurumuna sadakat, toplumsal iktidarın eşitsiz pay edilmesi (Wasko, 2007, s. 125) de eklemiștir. Metinlerarasılığın bir unsuru olan pastiş ve gizli alıntı bu noktada devreye girmektedir. Artık Grimmlerin masalından bahsedilemez hale gelmiştir. Disney öznesiz metini, sanki kendi ürünüymüşçesine bir gizli alıntı yapmıştır. Wasko (Wasko, 2007, s. 125), Disney'in masallara kendi ideolojisinin uzantısı olan detaylar ve sahneler eklemesini, yani müdahalesini, masalların Disneyleștirilmesi (Disneyfication) olarak belirtmektedir.

Masalı Disneyleștirme süreci, anlatıya masalın orjinalinden farklı olarak eklenen/ çıkarılan ve uzatılan sahnelerdir. Filmde pastişin karşımıza çıktığı yer, tekniğin, hikâyeden önce gelmesidir. Animatörlerce düzenlenmiş görüntüler seyirciye çok cazip biçimde 
anlatılır. Hikâye görüntülerle kusursuz bir bütünlük içinde sunulur ve izleyici kendisini büyülü bu dünyaya kaptırır (Zipes, 2006, s. 207). Müzik, pastişin yaratıldığı önemli bir unsurdur ve Disney filmlerinin karakteristiğini paylaşır; karakterler ve tema müzik ile kurulur ve geliştirilir (Wasko, 2007, s. 131). Bu süreçte, animasyon filmler için kullanılan ve yapaylığa dayandırılmış bir gerçeklik sunumu olarak tanımlanan hipergerçeklikten ${ }^{7}$ bahsetmek de mümkündür. Pamuk Prenses ve Yedi Cüceler'in yaratıldığı dönemi Disney'in biçimci dönemi olarak tanımlayan Chris Pallant'a (Pallant, 2010, s. 345) göre, bu dönemde anlatılar gerçeğe en yakın olacak şekilde tasarımlanmıştır. Bu duruma en iyi örnek Animatör Hamilton Luske'un açılkaması olmuştur: Pamuk Prenses'in gözleri insanların gözlerine benzer biçimde yuvarlak ve normal boyutlarda yaratılmıştır, diğer film kahramanları gibi Prensesin gözleri kocaman ve deforme edilmemiş tam tersi gerçeğe yakın tasarlanmıştır. Bir film olarak Pamuk Prenses, çocuk edebiyatının Disney tarafından yeniden yaratılmasıdır. Așağıdaki tablo 1'de Disney'in, Grimm Masallarında yaptığı temel değişiklikler sunulmuştur.

Tablo 1: Disney Filmi ile Grimm Masalları arasındaki temel farklar

\begin{tabular}{|l|l|}
\hline Grimm Masalı & Disney Filmi \\
\hline Pamuk Prenses 7 yaşındadır. & Pamuk Prenses 14 yaşındadır. \\
\hline $\begin{array}{l}\text { Anne ölür, baba sağdır. Pamuk } \\
\text { Prensesin kökeni detaylı anlatıır. }\end{array}$ & Ebeveyn yoktur. Pamuk Prensesin kökenine değinilmez. \\
\hline Pamuk Prenses çalışmaz. & Pamuk Prenses hizmetçi gibi çalıştırııı, sarayı temizler. \\
\hline $\begin{array}{l}\text { Avcıyı Pamuk Prenses ikna eder, bundan } \\
\text { sonra avcı prensese merhamet gösterir. }\end{array}$ & $\begin{array}{l}\text { Avcı, prensese acır ve ona akıl vererek } \\
\text { ormana gitmesini tembih eder. }\end{array}$ \\
\hline Prens önemsiz roldedir. & Prens filmde ön plandadır. \\
\hline Kraliçe kanibalizmin8 sembolüdür, ciğer yer, kan içer. & $\begin{array}{l}\text { Kraliçe, Pamuk Prensesin kalbini ister. } \\
\text { Kanibalizm simgesi silinmiştir. }\end{array}$ \\
\hline Orman ürkütücüdür. & $\begin{array}{l}\text { Ormandaki hayvanlar Pamuk Prensesi } \\
\text { cücelerin evine götürür. }\end{array}$ \\
\hline $\begin{array}{l}\text { Cücelerin evi temiz ve düzenlidir. Prenses cücelerin } \\
\text { yemeklerinden yer, onların yataklarında yatar. }\end{array}$ & $\begin{array}{l}\text { Cücelerin evi kirli ve dağınıktır. Prenses evi toplar, } \\
\text { yemek yapar ve yorgunluktan uykuya dalar. }\end{array}$ \\
\hline Cüceler altın madeninde çalışırlar. & Cüceler, pırlanta madeninde çalışılar. \\
\hline Cüceler anonimdir. Mütevazı bir roldedirler. & $\begin{array}{l}\text { Cüceler karakterlere sahiptir. Cücelerin eylemleri } \\
\text { sayesinde anlatı komediye olanak sağlar. }\end{array}$ \\
\hline $\begin{array}{l}\text { Kraliçe, Pamuk Prenses'i öldürmek } \\
\text { için cücelerin evine üç kez gider. }\end{array}$ & $\begin{array}{l}\text { Kraliçe, Pamuk Prenses'i öldürmek için } \\
\text { sadece bir kez cücelerin evine gider. }\end{array}$ \\
\hline $\begin{array}{l}\text { Kraliçe Pamuk Prenses'in düğününde kızgın demir } \\
\text { ayakkabılarla ömür boyu dansa mahkûm edilir. }\end{array}$ & $\begin{array}{l}\text { Kraliçe, cüceleri öldürmeye çalışırken } \\
\text { uçurumdan düşer ve ölür. }\end{array}$ \\
\hline $\begin{array}{l}\text { Cüceler tabutu taşırken tökezler ve } \\
\text { Pamuk Prenses hayata geri döner. }\end{array}$ & $\begin{array}{l}\text { Pamuk Prenses, prensin kendini } \\
\text { öpmesi ile hayata döner. }\end{array}$ \\
\hline
\end{tabular}

Kaynak: (Inge, 2004, s. 137; Wasko, 2007, ss. 129-130)

Disney'in çizelgede de gösterildiği gibi yaptı̆̆ı değişiklerin temelde nedeni filmin yapıldığı dönemin koşullarına uyarak Amerikan ideolojisinin vurgulanmasıdır. Pamuk Prenses filminde çalışma ahlâkına bağlılık, cüceler ile simgeleştirilmiştir. Cüceler, görev bilinciyle madenlerine giderlerken bunu anlatan şarkılar ve ıslıklar da bu bilinci pekiştiren unsurlar sunulur. Cüceler, ekonomik depresyonu hükümetle birlikte sirtlanan mütevazı Amerikan çalışanlarıdır. Bunun yanında Pamuk Prenses'in, sarayı ve cücelerin evini temizlemesi de çalışma gayretini ortaya koyar. Var olan durumundan kaçış ve buna yardım eden sihir teması filmde prenses üzerinden anlatılır. Prenses, kötü kraliçeden uzaklaşmak, hayalindeki prensle evlenmek ister bunu sürekli şarkılarında dile getirir. Kaçışı, kendi başına yapamaz ona yardım eden ise cücelerdir (Wasko, 2007). Aşk sadece, duygusal düzlemde yaşanmaz, filmde sunulan Pamuk Prenses'in tek arzusu, yaşamındaki 
nihai hedefi, bu aşkın kamu tarafından onay görmüş hâli olan evliliktir (Özsel, 2017, s. 54). Așk ve mutluluk teması, prensin prensesi öpmesi ve evlenmeleriyle gerçekleşir. Ahlâkçılık unsuru, kötüye karşı iyilerin zaferiyle anlatılır. İyi ödüllendirilirken, kötü cezalandırılır. Adalet, iyi ve kötü ayrımıyla dağıtılır. Aile, filmde cüceler ve Pamuk Prenses'in mutlu bir aile ortamı kurmalarıyla anlatılır. Bununla birlikte Pamuk Prenses'in prensle evlenerek kendi mutlu yuvasını kurması da aileye yapılan vurgudur. Prenses için 'beyazatlı prensle' evlenme, masumiyet, mutlu son, pasif kadın gibi temalar Batı kültüründeki kadının kamusal konumunu da ortaya koymaktadır (Inge, 2004, s. 141; Wasko, 2007, ss. 129-130).

Grimm masalı ile Disney filminin ortak bir noktada buluştuğundan bahseden Zipes (Zipes, 2006, s. 204), Disney'in Grimmlerin müridi olarak düşünülebileceğini belirtir. Kadının toplumsal konumu hakkında Disney, Grimmlerin kadın stereotiplerini korumuş ve devam ettirmiştir. Her iki anlatıda da kadınlar bir başka kadınla, erkeğin onayını alabilmek için karşı karşıya gelirler. Kadınlar ne yaparsa yapsınlar kendi yaşamlarında erkeğin müdahalesi olmadan var olamazlar. Kadınlar iki anlatıda da masumdur, ev işleriyle sunulurlar, güzel ve iyidirler. Kötü Kadın tipi ise, huzur ve düzen bozucu, hırslı ve erotik unsurlarla sunulur.

Disney'in Grimm masalını değiștirmesinde dinî öğretilerden uzaklaşma çabası olduğunu vurgulayan Enikö Stringham’a göre (Stringham, 2011), Grimm Kardeşler, masalda yedi rakamı ile Hristiyanlığa göndermede bulunmuş ve dünyanın yedi günde yaratıldığını hatırlatmıştır. Masalda, prenses yedi yaşındadır ve yedi cüceler de buna göndermedir. Disney'de prensesin yaşı büyür, ilk sahnede gelecekteki prensiyle tanışır ve ona âşık olur. Pamuk Prenses'in yaşının büyütülmesiyle birlikte bu dinî göndermeyle olan ilişki koparılarak parodi de sunulmuş olur. Disney, prensesi dönüştürmüştür. Artık prenses Grimmlerin yedi yaşındaki naif prensesi değildir; o, on altı yaşında aşk yaşamaya hazır bir genç kadındır. Disney, tamamen Hristiyan öğretilerine göndermelerle ilişkiyi kesmeye çalıșmıştır. Grimmlerin masalında Pamuk Prenses'in annesinin eline iğne battığında üç kandamlası akar. Masalda üç kadın vardır. Kötü kraliçe (Kraliçe), Pamuk Prensesi üç kez öldürmeye çalışır. Üç rakamı ise Hristiyanlıkta teslisi veya üçleme denen Tanrı, babaoğul ve kutsal ruhtan oluşan öğretiye gönderme yapmaktadır. Masalda cüceler, prenses öldükten sonra üç gün yas tutarlar. Bu, İsa'nın öldükten üç gün sonra yeniden doğmasına bir göndermedir. Anlatıda yapılan bir başka değișiklik ise organlardır. Grimm kardeşler karaciğeri ve akciğeri belirtirlerken, Disney kalbi ister. Karaciğer en büyük organlardan biridir, kanın en fazla bulunduğu organdır ve en siyah olanıdır. Platon'un ve takipçilerinin karanlık tutkuların, öfkenin, kıskançlığın, açgözlülüğün işareti olarak kullandığı karaciğer, Disney'de kalple sonlanır. Disney çocukların ve ailelerin izleyeceği filmde karaciğerin yerine sevginin simgesi kalbi koymuştur.

\section{Yeşilçam'da Masallar}

İlk kez George Melies'ın, 1899 yılında Charles Perrault'un Cinderella ${ }^{9}$ masalını sinemaya uyarlamasından 54 yıl sonra Türkiye'de de masal sinemaya uyarlanmıştır.1953 yılında Baha Gelenbevi'nin yönettiği Balıkçı Güzeli 1002 Gece Türk sinemasında uyarlanan ilk masaldır. Sonraki yıllarda ve altmışların ortalarına kadar masal tümden unutulmuş, hatta geçerli bir tür sayılmamış ve sadece üç film ${ }^{10}$ çekilmiştir. Yeşilçam’ın ekonomik sorunları ve televizyonun yaygınlaşması seyirciyi özellikle de aileleri sinema salonlarından uzaklaştırmıştır. Türk sinemasına fantastik türlerin girmesi ve masal furyasının bunun içerisinde kendisine yer bulması 1970’lerin başına denk gelmiştir (Tunç, 2012). 
Masal furyası içerisinde Yeşilçam'ı harekete geçiren öncü örnek Ertem Göreç'in yönetmenliğini yaptığı, gișe rekorları kıran Pamuk Prenses ve Yedi Cüceler (1970) adlı filmdir. Dönemin koşullarında Türk sinemasının, Walt Disney'in Pamuk Prenses ve Yedi Cüceleri'ni Hollywood'dan önce filme uyarlamış olması son derece şaşırtıcıdır. Masala dönüş Yeşilçam sinemasına yeni ufuklar açmıştır. 1971 yılı masal açısından verimli ${ }^{11}$ olmuş, zaman zaman Batılı kaynaklardan Doğulu kaynaklara ${ }^{12}$ da bir geçiş yaşanmıştır. Masal dünyası, Yeşilçam'a iyice yerleştikten sonra kendisine bir başka kaynak daha bulmuştur: Türk halk hikâyeleri. Klişe öyküsü, türküleri, pek değişmeyen kişileriyle Keloğlan bu filmlerin en önemli konusu ve karakteri olmuş ve bu sayede anıştırmanın kullanımına da olanak sağlamıştır. Yetmişlerin başında Yeşilçam’a yeni bir soluk getiren masal furyası iki sene içerisinde toplumsal uylaşımlara daha fazla cevap verememiş ve bitmiștir(Scognamillo \& Demirhan, 1999). Masal furyası bitmiş olsa bile Türk sinemasında masallara, onların kahramanlarına göndermeler yapan sinema filmleri üretilmiştir. 80’li yıllarda dünyada yaşanan neo-liberal politikalarla birlikte küresel üretim ve dağıtım koşulları Türkiye'de de hissedilmiștir. Bu tarihten sonra yerli yönetmenlerin masal uyarlama çalışmalarının sayısında düşüşler yaşanmıştır.

\section{Disney'in Sihirli Dünyası'ndan Yeşilçam Sokağı'na Uyarlanan Pamuk Prenses ve Yedi Cüceler: Ertem Göreç}

II. Dünya Savaşı sonrası sinema devletçe desteklenmişken profesyonel sinemaciların yetişmesi ile Yeşilçam hem nicelik hem de nitelik açısından değişim yaşamıştır. Sinemanın kârlı bir ticari iş alanı olduğu keşfedilmiş, ticari kaygıların etkisiyle melodram, güldürü ve fantezilere ağırlık veren salon filmleri yaygınlaşmaya başlamıştır. Filmlere talebin artması, kaynak olarak edebiyat eserlerine başvurmayı gerektirmiş, ciddi bir sinema birikimi ve senaristin olmadığı bu dönemde uyarlamalar revaçta olmuştur (Çetin-Erus, 2005). Gilbert Adair'in (Adair, 1993) belirttiği gibi Amerikan halkı ve dünyadaki pek çok toplum Grimm kardeşlerin Pamuk Prensesi'ni Walt Disney'den öğrenmiștir. Disney'in çizgi filmi, Türkiye'de ise ancak yetmişli yılların sonlarında televizyon yaygınlaştıktan sonra izlenmiştir. Ancak bu dönemden önce, Yeşilçam'da 1970 yılında Walt Disney'in uzun metrajlı Pamuk Prenses ve Yedi Cüceler filmi yönetmen Ertem Göreç tarafından yapılan uyarlamayla Türk seyircisiyle buluşturulmuştur. Aynı isimle uyarlanan film o dönem Türk sinema tarihinde önemli bir gișe hasılatı elde etmiştir. Hatta bu dönemde film, İtalya'ya 8500 \$' ${ }^{13}$ satılmış ve çeşitli festivallerde de ödül ${ }^{14}$ almıştır.
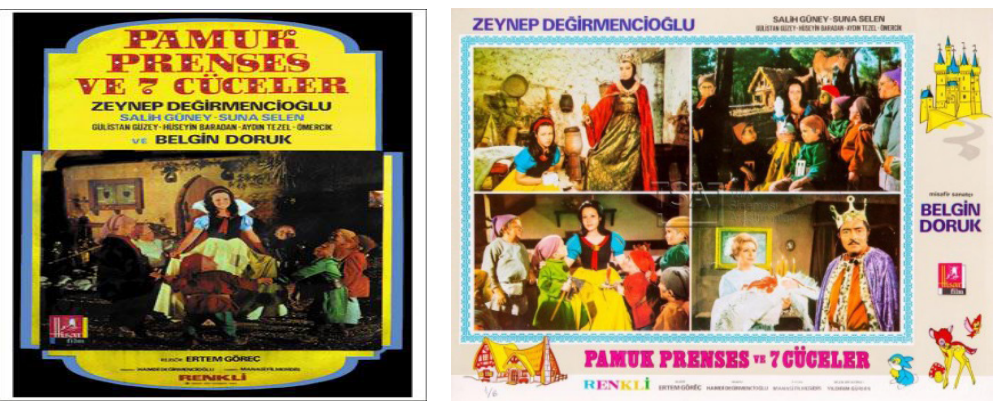

Görsel 3: Pamuk Prenses ve Yedi Cüceler Film Afişi ve Filmden çeşitli sahneler Kaynak: (https://www.tsa.org.tr 2020)

Göreç'in filmi sayesinde Walt Disney'in Pamuk Prenses ve Yedi Cüceler'i bilinirlik elde etmiştir. Çünkü Ayşe Şasa'nın da (Şasa, 2002) belirttiği gibi geçmişte masal dinleyicisi olan halk, masal izleyicisine dönüşmüştür. Yeşilçam'ın uyarlama filmlerinde çoğu zaman Hollywood'daki 'kitap avcları'nın ya da ajansların rolünü üstlenen profesyoneller olmadığı için metnin seçiminde yönetmen ve senarist insiyatif almıştır (Çetin-Erus, 
2005). Masal furyasının başlamasına neden olan Pamuk Prenses ve Yedi Cüceler filminin uyarlamasında ise Senarist Hamdi Değirmencioğlu insiyatifi kullanan kişi olmuştur. Ertem Göreç (E. Göreç, kişisel iletişim, Subat 2018) bu durumu şu şekilde anlatmaktadır:

\begin{abstract}
“Pamuk Prenses rolündeki Zeynep Değirmencioğlu, senarist Hamdi’nin kızı. Bir baba olarak Hamdi kızına çok inanmış ve ona uygun senaryolar yazmıștır. Örneğin Zeynep sekiz yaşına geldiğinde çocuk filmlerinin başlangıcı sayılan Ayşecik'i yazmıştır. Bu film furyası bitince Zeynep on altı yaşına gelmiştir. Kızının bu yaşına uygun konular ararken bir gün Walt Disney'in Pamuk Prenses ve Yedi Cüceler'ini izlemiș ve bunun uyarlama senaryosunu yazmıș. Senarist Değirmencioğlu yaşı ilerleyen kızına çocuk başrol yerine genç kız rolünde oynaması için film çekmek istediğini bana ve yapımcımız Özdemir Birsel'e belirtti”.
\end{abstract}

Senaristin kızının filmde başrol oynamasının yanı sıra filmin yapımcısı Özdemir Birsel'in eşi, oyuncu Belgin Doruk, filmde Pamuk Prenses 'in annesi rolünde yer almıştır. Bu açıdan filmin, Disney'in kullandığı anlatı ekonomisini oldukça başarılı şekilde kullandığını belirtmek yanlış olmaz (Moen, 2013, s. 180). Hatta Disney'in yapmış olduğu gibi Kötü Kraliçe ile Cadı, Göreç'in filminde de aynı oyuncuya oynatılmıştır. Suna Selen'in oynadığı bu iki karakterin, aynı oyuncu tarafından oynandığının anlaşılmaması için uzun süren makyaj ve özenli kostüm seçimlerine (E. Göreç, kişisel iletişim, Subat 2018) zaman ayrılmıştır.

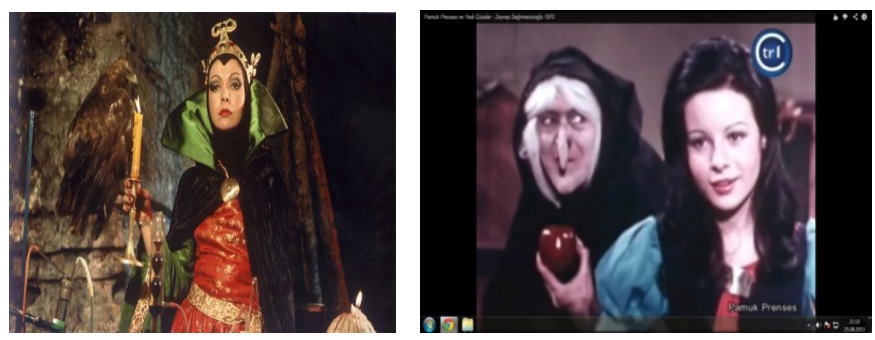

Görsel 4: Tek oyuncunun iki karaktere bürünmesi

Kaynak: (sinematikyesilcam.com 2020)

Kostümlerin hazırlanmasında da ekonomik davranıldığını yönetmen Ertem Göreç (E. Göreç, kişisel iletişim, Subat 2018) kendisiyle yapılan söyleşide şöyle belirtmektedir: “...maliyet kaygısının yanında estetik açıdan da kaygımızı rahatlatan bir unsur da öz anne rolünü oynayan yapımcımızın eşi Belgin Doruk'un kostümlerin üretilmesi ve tasarımlanmasına yardım etmiş olmasıdır". İki karakterin tek bir oyuncu tarafından oynatılması konusunda oldukça titiz davranılması ve iyi oyunculuk sayesinde Suna Selen, 1971 yılında sekizinci Antalya Altın Portakal Film Festivali'nde en iyi yardımcı kadın oyuncu ödülünü almıştır.

Nilgün Abisel'in (Abisel, 1999) belirttiği gibi Yeşilçam, her zaman ticari kaygllar içinde Hollywoodvari popüler film anlatılarından biri olan yıldız kullanımına bağlı kalmıştır. Pamuk Prenses ve Yedi Cüceler filmi de yıldızları kullanmıștır. Filmin başrollerinde Türk sinemasının Ayşeciği çocuk yıldız Zeynep Değirmencioğlu (Pamuk Prenses), Belgin Doruk (Anne Kraliçe), Salih Güney (Yakışıklı Prens), Suna Selen (Kötü Kraliçe) oynamıştır. Filmin ortaya çıkma sürecini Yönetmen Ertem Göreç (E. Göreç, kişisel iletişim, Subat 2018) şu şekilde anlatmaktadır: "seyircinin ihtiyacına göre filmleri yaparken çoğunlukla başrolleri yıldızların oynamasına gayret ediyorduk". Pamuk Prenses filmi seyircinin çok sevdiği popüler bir film olmuş ancak Filiz Bilgiç'in (Bilgiç, 2002) de belirttiği üzere halkın beklenti, kültür ve mitoslarına da denk düşmüştür. Film çekilirken konu Grimm Kardeşler yerine Disney'den hazır alınmış ancak uyarlama sırasında yerli unsurlar filme serpiştirilmiştir. 
Metinlerarasılık, uyarlama sırasında yerlileştirme unsurlarıyla karşımıza çıktığı gibi, en belirgin örneği cücelerde gözlenmektedir. Filmin yapımcısı ve senaristi filmde seyircinin gerçek hayattan izler bulması durumunda daha çok gişe hasılatı yapılacağı düşüncesinden hareketle filmde cüce insan oynatma kararı vermişlerdir (E. Göreç, kişisel iletişim, Subat 2018). Bunun üzerine çekimler başlamadan önce ulusal gazetelere 'filmde oynatılmak üzere' ibaresi bulunan ilân verilmiştir. İlâna Türkiye'nin pek çok yerinden başvurular yapılmış, seçmeler sonrasında mesleği oyunculuk olmayan yedi cüce ${ }^{15}$ seçilmiştir.

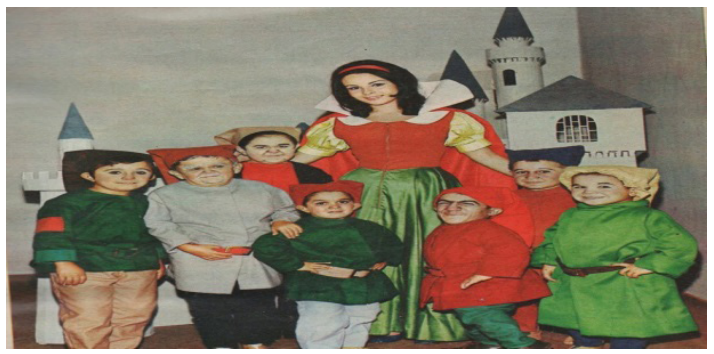

Görsel 5: Filmde oynayan Yedi Cüceler

Kaynak: (https://bluesperisan.blogspot.com: 2020)

Türk sinemasında ilk kez cüce insanlar oynatılarak bir çı̆̆ır açılmıştır. Yedi cüceler bu filmden sonra ünlü olmuş ve pek çok filmde rol almıştır. Cüceler, tıpkı Disney filminde olduğu gibi Göreç'in filminde de karakterlere sahiptirler ve filmde hepsi birer birer seyirciye anlatılmaktadır. Göreç'in cüceleri Disney'in cücelerinden daha komik resmedilmeye çalışılmıştır. Yönetmen Göreç (E. Göreç, kişisel iletişim, Subat 2018) bu durumu bilinçli yarattığının altını çizerek şunları demektedir: "Çizgi filmin oyuncularla çekilmiş versiyonu bizim filmimiz. Ama Disney'in filminin içine biz kendi ülkemizin esprilerini, davranışlarını yerleştirdik ki aileler filme gelsin”. Göreç, metinlerarasılıkta en sık kullanılan anıştırmayı kullanmış, en komik cüceyi sınırlarını zorlayarak Türk halk hikâye kahramanlarından biri olan Keloğlan hâline getirmiștir. Cüce Keloğlan ${ }^{16}$ sözünün eri, biraz sakar, cesur, kurnaz, hakkaniyetlidir tıpkı halk hikâyelerinde olduğu gibidir. Türk halk hikâyelerinde Keloğlan, boyunun küçüklüğüne, güçsüzlügü̈ne rağmen yaşından ve boyundan; hâlinden ve görünüşünden hiç de beklenmeyecek maharetler sergiler, kurnazlıklar ve hileler yardımıyla düşmanlarını alt eder (Alangu, 2016). Göreç'in Keloğlan karakterini kullanması, Batılı bir masaldan doğrudan alıntı yapıp onu yerlileştirerek Türk izleyicisine sunması açısından dönemine göre dâhice bir buluştur.

Bir başka yerlileştirme unsuru ise filmin müzikleridir. Film müziklerini Yıldırım Gürses düzenlemiştir. Gürses operadan, sanat müziğine ve hatta popüler müzik gibi pek çok türde ürünler vermiş çok yönlü bir müzisyendir. Gürses'in bu çok yönlülüğü Türk izleyicisinin Disney uyarlaması bir filmi sevmesine yarayacak müzikler bestelemesine neden olmuştur. Ne Güzel Şey Yaşamak isimli sanat müziği formundaki besteyi de bu film için bestelemiştir. Disney'in filminde olduğu gibi komedi unsuru cüceler aracılığıyla sağlanmaktadır. Ancak yönetmenin de belirttiği üzere cücelerin komedisi Türk halkının beğenilerine göre uyarlanmış ve halkın mizahına uygun olacak biçimde resmedilmiştir. Örneğin; öfkeli şirinin yıkanmak istememesi üzerine diğer cüceler tarafından gölete atılması izleyiciyi çok güldürmüştür. Cücelerin kendi arasındaki şakalaşmaları ve diyalogları OsmanlıTürk tiyatro tarihindeki önemli karakterlerden Karagöz ve Hacivatvaridir. Aşağıda örneklendirilen diyaloglar, iyi bir anıştırma örneği olarak tıpkı Hacivat ile Karagöz'ün konuşmaları gibidir.

Neşeli: ...ne kadar çok çalışmışsın

Keloğlan: ...tabi çalıştım canım, hayatımın çöp tenekesi 
Neșeli: ...ruhumun ekmek tenekesi

Keloğlan: ...canımın fıstığı

Neşeli: ...ruhumun helvası, hayatımın aynası

Keloğlan: ...gel buraya lan eniştemin kaynatası (Göreç, 1970)

Grimm masalında cüceler evlerine gizlice girmiş Pamuk Prenses'in sabaha kadar uyumasına izin verirken, Disney, Prenses'i cücelerle sabahı beklemeden tanıştırır. Akşam yemeği sonrası şarkı söyleyip dans eden Disney karakterleri Göreç filminde ise bir anda orkestra üyeleri hâline gelir ve her biri farklı müzik aleti çalarak (piyano, kontrbas, keman, marakas, bongo, üçgen zil, trompet) şarkı söylerler. Disney'in uyarlaması yapılırken yerlileştirme unsurlarından bir başkası ise Türk halkının o dönem çok sevdiği melodramatik anlatıyı kullanmasıdır. Melodram anlatı yapısı içine zaman zaman yan karakterlerle sokulan güldürü unsurları ve ille de bol şarkılı sahneler filmin vazgeçilmezidir. Pamuk Prenses ve Yedi Cüceler'deki melodram anlatıları şu şekilde örneklendirilebilir: Kraliçe, prens ve prensesi birlikte konuşurken görür ve kıskanır. Bunun üzerine askerlerini onları yakalaması için yollar. Prens yolda giderken bir anda karşısına kötü askerler çıkar ve prens, tek başına on askerle savaşır. Bu sırada küçük çocuk yardımına koşar ve onlar askerleri yenmeyi başarırlar. Bu sahneler Yeşilçam'ın tarihsel fantazya furyasının tek başına ordulara meydan okuyan yerli kahramanlarına göndermeler yaparak çok daha fazla seyirciyi filme çekmiştir. Disney'in anlatısına ekleme yapılan unsurdan bir tanesi de prensin yanında ona arkadaşlık eden ve hatta kimi zaman akıl veren bir erkek çocuktur. Bu erkek çocuk prensin her zora düştüğü noktada akıl veren kişisi bir nevi Vladamir Propp'un (Propp, 2017) yardımcısı ve Türk halk hikâyelerinin bilge kişisidir.

Göreç'in popüler seyirciye hitap eden uyarlaması Walt Disney'in değişmez mutlu son formülüne uymuş ve seyircinin beklentilerini yerine getiren; aile, evlilik bağı, iktidarı ele geçirme gibi kodları (Tunalı, 2017, s. 368) sıralanmıştır. Göreç'in uyarlaması Disney'de olduğu gibi gayet basit yapıdadır. Bu yapı dokuz bölümü içmektedir: Köken (kahramanın doğumu), kıskançlık, kovma, kabul, yeniden kıskançlık, ölüm, sergileme, canlandırma, çözüm (Inge, 2004, s. 137). Göreç, Disney gibi birinci bölüme filminde yer vermez, yani Pamuk Prenses'in doğumu ve öncesine değinilmez. Diğer tüm bölümleme Disney'in anlatısıyla aynıdır. Bunun yanında filmde, Disney'in yaptığı gibi hayvan çeşitliliğine önem verilmiştir. Hayvanları film setinde oynatma fikri ise kostüm sorumlusu Niyazi Er tarafından önerilir. Göreç (E. Göreç, kişisel iletişim, Subat 2018) film setinde hayvanları kullanma konusunda filmin çekildiği Antalya'nın Serik İlçesi'nde dağ köylülerinin de yardımı olduğunu belirtmektedir. Köy çocuklarından birinin filmdeki ceylanı evcilleștirdiğini bu nedenle de filmde ceylanı kullanabildiklerinden bahsetmektedir. Kostüm sorumlusu Niyazi Er'in ise hayvanların pek çoğunu bir ay boyunca eğitmeye çalıştığını da eklemektedir. New York gösteriminden sonra eleştirmenler Disney'in gelecekteki filmlerini pazarlama yolu olarak hayvanları seçmesinin çok önemli olduğuna (Inge, 2004, s. 138) değinmişlerdir. Bu açıdan Tıpkı Disney gibi Ertem Göreç'in de filmini pazarlamak için hayvanları kullanması akıllıca bir yöntemdir.

\section{Sonuç}

Sözlü kültür içinde toplumların hayal gücüyle yaratılan masallar aktarımlar yoluyla günümüze kadar gelmiştir. Masalların günümüze kadar gelmesinde metinlerin değiş tokuşları önemli bir etken olmuştur. Metinlerarasılığın izleri, masalların yeniden üretim sürecinde olay örgüsü, konu anlatımı, kahramanlar, mekân, zaman gibi pek çok unsurun değişikliğinde bulmak mümkündür. Alıntı, gizli alıntı, anıştırma, parodi ve pastiş gibi 
kullanımların görülebileceği masallardan biri olan Pamuk Prenses ve Yedi Cüceler sözden yazıya geçirildikten sonra defalarca yeniden üretilerek dönüştürülmüştür. Daha önce değinildiği üzere metinlerarasılıkta yazar, okur ve dış etkenler temeldir. Bu noktada incelenen metinler arasındaki göndermelerin çoğunlukla açık şekilde yapıldığını söylemek yanlış olmayacaktır. Değişimler zamana, mekâna, toplumların kültürlerine göre farklılık ve pek tabi benzerlikler göstermiştir. Çalışmaya konu edinilen değişim unsurları Grimm Kardeşler, Walt Disney ve Ertem Göreç üzerinden örneklendirilmiştir.

Wilhem ve Jakob kardeșler 1812 yılında masalı yazıya dökerken değiştirmiş ve dönemin toplumsal koşullarına uyarlamışlardır. Grimmler, Pamuk Prenses ve Yedi Cüceler'de kadını hane içinde, erkeği kamusal yaşamda, Hristiyan öğretilerini gündelik yaşamda tanımlayarak dönemin egemen belirleyici burjuva ideolojisini masalların içerisine yerleștirmişlerdir. Bu sayede de sözlü halk geleneğini yaratan sıradan insandan masalı uzaklaştırmış ve masalı ehlileștirmiştirler.

1937 yılında ekonomik buhranla baş etmeye çalışan Amerikan halkının ruh halini iyileştirmek ve bütçesinden bir kısmını sinemaya ayırmaya ikna etmek için Walt Disney, Grimmler'in masalını çizgi filme uyarlamıștır. Disney, uyarlamayı yaparken Amerikan seyircisinin sinema seyretme pratiklerini göze alarak masalda değișiklikler yapmıştır. Masalı ortaya koyarken ise Grimm'lerin metinini okumuş ve geçmiş deneyimlerine de değinmiştir. Masalın öyküsünde eksiltmeler yaparken, kahramanlarının masal içindeki ağırlıklarını da değiştirmiştir. Seyircinin seksen dakika sinema salonunda kalmasını sağlamak için masalın ağır Hristiyan öğretilerini ortadan kaldırıp yerine komedi unsurlarını eklemiştir. Masalda yaptığı en belirleyici değişiklik vurgusu ise kendi deneyimlerinden de yola çıktığı, Amerikan ideolojisi olmuştur. Buna göre, çalışma ahlâkı, vatanperverlik, bireycilik, kapitalizm, aile kurumunun kutsallığı, toplumsal iktidarın eşitsiz pay edilmesi gibi değerler masala yerleştirilerek Grimm anlatısından farklı bir yapıya büründürülmüştür. Kristeva'nın da belirtmiş olduğu gibi, çeşitlilikler bir araya getirilerek Grimm masalı asimile edilmiş yeni bir metin ortaya koyulmuştur.

1970 yılında Ertem Göreç de, Disney gibi ekonomik sıkıntılar yaşayan Yeşilçam sinemasına yeni bir soluk getirmek, seyirciyi yeniden salonlara çekmek için Disney'in çizgi filmini filme uyarlamıştır. Dönemin Yeșilçam sinemasında ticari kaygıların etkisiyle melodram, güldürü ve fantezi ağırlıklı salon filmlerine bir yenilik olarak masala başvurmuş olan Göreç, Disney anlatısına olabildiğince bağlı kalmaya çalışmış ancak Türk sinema seyircisinin beğenilerini ve beklentilerini de göz ardı edememiştir. Dönemin önemli bir anlatı unsuru olan çocuk oyuncu kullanılmış bununla birlikte yine dönemin özelliği olan yıldız oyuncu filmin önemli vurgularından biri olmuştur. Göreç, metinlerarasılıktaki alıntıyı çok iyi kullanmış; Disney'in anlatısına sadık kalabilmek için kostüm, mekân, makyaj gibi unsurları incelikle işlemiştir. Disney'de olduğu gibi Göreç de masalın anlatısına komedi unsuru koymayı ihmal etmemiş hatta bunun oranını arttırmış ve filmi parodi haline getirmiştir. Göreç'in komedi unsurunu kullanması ise bir başka metinlerarası unsuru anıştırmayı da kaçınılmaz kılmıştır. Türk sinema seyircisinin ilgisini çekmek için yedi cüceleri gerçek cücelerden seçmiş, cücelerden birini Türk masal kahramanlarından Keloğlan haline getirmiş ve dönemin tarihsel fantazya filmlerini anımsatan sahneleri filme eklemiştir.

Makalede yer verilen Pamuk Prenses ve Yedi Cüceler'in yazılı masal formu, çizgi filmi ve uzun metrajlı filmi metinlerarasılığa birer örnek oluşturmuştur. Masalın yeniden üretimlerindeki değiş tokuşlara bakarak Almanya, Amerika ve Türkiye gibi farklı 
coğrafyalarda ve 1812, 1937 ve 1970 gibi farklı zamanlarda masal anlatısındaki değișikliklerin ve benzerliklerin neler olduğunun belirlenmesi mümkün olmuştur. $\mathrm{Bu}$ sayede de masalın toplumsal bir metin haline dönüșerek günümüze kadar geliş serüvenini değerlendirmek, bu metnin toplumsal tarih içindeki sürekliliğinin anlaşılmasına bir katkı sağlamaya çalışılmıştır. Bu noktada 207 yıl önce yazılı hale getirilmiş olan Pamuk Prenses ve Yedi Cüceler'in günümüze kadar metinlerin değiş tokuşları ile karşımızda olması edebiyattan, halkbilimine, iletişimden, sinemaya kadar pek çok disiplinin ilgi alanına girmesi masalların yok olmadan daha yüzlerce yıl yaşayacağına bir işaret olarak değerlendirilebilir.

\section{Notlar}

1 Çatışmanın sebebi, masalların hep söylenegeldiği gibi gerçekdışı olay ve karakterlerin inanılması zor serüvenlerinin hikâye edildiği fantastik metinler olmamasıdır. Masallar, içlerinde sömürünün, haksızlıkların, eşitsizliklerin itaat ve boyun eğişlerin, isyan ve başkaldırıların, emeğin kutsallığının, sınıfsal düzen ayrımlarının kutsalının, dayanışma ve mücadelenin gerekliliğinin, özgürlükte arayışlarının, sevginin edilgenleştirici işlevlerinin, yoldan çıkmanın, yola getirmenin, yenginin ve bozgunun, sevginin ve nefretin vb. daha pek çok insanlık hâllerinin yuvalandığı realist metinlerdir (Köse, 2015, s. 12-13).

2 Grimm Kardeşler yükselen orta sınıf tarafından sıradan insanların zengin kültürel geleneklerinin kabul edilmesini sağlamlaştırmışlardır. Sözlü geleneğe sahip olan köylü ve işçiler okuma yazma bilmediklerinden yazılı masalı da tüketmeleri mümkün değildir. Grimm kardeşler, bu sözlü hikâyeleri basılı eseri okuyabilen burjuva sınıfı için yeniden düzenlemişlerdir. Düzenlenen bu anlatıda, iktidar ilişkileri, yaşamda kalma, özerklik için mücadele modelleri ve toplumsal cinsiyet rolleri (Zipes, 2006, s. 61) gibi unsurlar bulunmaktadır.

3 Kısa vadede ortalama bir başarı durumundaysa, yapıtın giderleri, yazar hakkı ve dağııı giderleri çıkarıldıktan sonra satılamayan ciltlerin parasını çıkarabilmesi, stoklarıı parasal olarak karşlayabilmesi, genel giderleri ve vergileri ödeyebilmesi için yayıncının elinde satış fiyatının yaklaşık \% 20'si kalmaktadır. Ama bir kitap piyasada bir yılı aşan bir süre kalarak 'işletme değeri' kazandığında uzun vadeli bir kestirim ve yatıım 'piyasası'nın temellerini oluşturan parasal bir 'yönelteç' durumuna gelir: Birinci baskı sabit masrafları karşıadığında, kitap oldukça düşük maliyet fiyatıyla yeniden basılabilir ve böylelikle, şirket sermayesinin sonunda büyümesini sağlayacak biçimde az çok riskli yatııımları finanse etmeye olanak tanıyan düzenli gelirleri (dolaysız gelirler ve yanı sıra ek gelirler, çeviriler, cep kitabı baskıları, televizyona ve sinemaya satış) güvence altına alınır (Bourdieu, 2006, s. 230).

4 Edebî eserlerde hikâye olduğundan ya da senaryonun çatısı oluştuğu için projeleri hazırlama evresinde gerekli kararları vermek, fikir alışverişinde bulunmak, yardımcı yapımcılar aramak, yönetim ve rol konularını açıklı̆a kavuşturmak, üretim masraflarını hesaplamanın yapım öncesi sağladığı kolaylıklar nedeniyle sinema uyarlamalara yönelmiştir (Cansız, 2011, s. 37).

5 Pamuk Prenses pek çok animasyona uyarlanmış veya mutasyona uğratılmıştır. Masaldan temel öykü ve ikonografiler alınmış -kötü kraliçe, konuşan ayna, cam tabut gibi- ve dönüşüme uğratılarak filmleştirilmiştir. Bu uyarlamalar eski masalları dönüştürmüş bunu ise kentsel yapıları ve modern müzikleri kullanarak yapmışıı. Pamuk Prenses uyarlamalarının kimileri; gizemli mağaranın bir anda Coney Adası veya Manhattan karışımı olması gibi modern hayata gönderme yapmaktadır (Moen, 2013, s. 176)

6 Disney ve animatörleri, sosyal şartlara ve kültüre göre izleyicilerin film anlayışlarını genişleten yenilikler hazıılamışlardır. Ama aynı zamanda masalların metalaşmasına sebep olan mekanik yeniden üretimin geriletici kullanımını yaratmışlardır. Film görüntüleri, masalların aurasını parçalamış ve animatörlerin zekâsını ve ustalığını kutlamışlardır. Illk dönem filmler, özellikle izleyicileri filmlere hayran bırakmak ve animatörlerin büyülü yeteneklerini ifade etmek için geleneksel hikâyelerle eğlenmek ve teknolojiyi geliştirmek için bir araç olmuştur (Zipes, 2006, s. 197).

7 Eco ve Baudrillard'ın tartıştıkları hipergerçeklik terimi animasyon çalışmalarında farklı ve özgün bir anlamda tartışılmışıır. Hipergerçekliği, Paul Wells animasyon çalışmalarına uyarlamıştır. Animasyon çalısmalarında hipergerçeklik, yapaylığa dayandııımış bir gerçeklik sunumu olarak tanımlanmaktadır (Pallant, 2010).

8 Kanibalizm (Canibalizm), türkçeye yamyamlık olarak çevrilmektedir. Terimin anlamı, aynı türdeki canlıların birbirini yemesidir (Sarı ve Ercan, 2008).

9 The Little Glass Slippe olarak da kullanılmaktadır.

10 Cilalı ibo ve Kırk Haramiler (Mehmet Dinler, 1964), Kelajıı Bir Keloğlan (Yavuz Yalınkılınç, 1965) ve Bağdat Hırsızı (Ertem Göreç, 1968) (Scognamillo \& Demirhan, 1999, s. 15). 
111971 yılında 17. Yüzyıl Charles Perrault'un Külkedisi Sindirella uyarlaması Saraylar Meleği isimle Aram Gülyüz tarafından ve Sindirella Külkedisi (1971) ismiyle Süreyya Duru tarafından filme uyarlanmıştır (Scognamillo \& Demirhan, 1999, ss. 1920).

12 Bir Varmış Bir Yokmuş (Sırrı Gültekin, 1971), Ali Baba ve Kırk Haramiler (0. Nuri Ergun, 1971), Altın Prens Devler Ülkesinde (Muharrem Gürses, 1971), Şehzade Sinbad Kaf Dağında (Muharrem Gürses, 1971).

13 Türk-Film Sinema Dergisi'ne göre, Yerli filmlerin yurt dışına ihracı o dönem devam etmekte ve bu arada bir hayli yüksek fiyatla yabancı ülkelere ihracat yapıımaktadır. En pahalı satılan üç filmin isimleri ve satıldığı ülkeler şöyledir: 1) Ayrı Dünyalar (And Film) Turgut Demirağ'ın yönetmenliğini yaptığı bu film Sovyetler Birliği'ne 10.000 dolara satılmıştır. 2) Pamuk Prenses ve 7 Cüceler (Hisar Film) Ertem Göreç'in yönetmenliğini yaptığı bu film İtalya'ya 8.500 dolara satılmıştır. 3) Çanakkale Aslanları (And Film) Turgut Demirağ'ın yönetmenliğini yaptığı bu film de Filipinler Cumhuriyeti'ne 7.800 dolara satılmıştır.

14 Antalya Film Şenliği (1971) En İyi Üçüncü Film Ödülü, En lyi yardımcı Oyuncu (Ertem Göreç, t.y.)

15 Ses Dergisi'nin 1970 yılının ekiminde çıkan kırk ikinci sayısında Pamuk Prenses ve Yedi Cüceler filmi için seçilen yedi cüceler tanıtıımışıı. 13 Şubat 1971 yıında Ses Dergisi yine Yedi Cüceleri sayfalarına taşımış ve dönemin Cumhurbaşkanı Cevdet Sunay'ın Çankaya köşkünde Yedi cüceleri ağırladığından bahsetmiştir (Yedi Cüceler Çankaya Köşkünde, t.y.).

16 Keloğlan karakterini canlandıracak olan Aydın Babaoğlu filmin ardından çok ünlenir hatta diğer cüceler içinde en ünlüsü o olur. Film sonrası Yeşilçam onun peşine düşer. 1971'de Biricik iş Başında (Yılmaz Atadeniz)adılyla çekilen filmde afişe Cüce Aydın Babaoğlu diye yazılarak kendisine payesi verilmiştir. Sonrasında ise Babaoğlu, birbiri ardına çekilen Keloğlan filmleriyle Rüştü Asyalı'ya eşlik eden karakter oyuncu olarak perdelerde görünecektir. 1974'e gelindiğinde ise Babaoğlu, Yeşilçam'da bir Lucky Luke (Redkit) çizgi roman uyarlaması olan Atını Seven Kovboy'da (Aram Gülyüz) Daltonlar'ın Joe Dalton’u olarak rol almıştı (Blues Perişan: 1970’de “7 Cüceler” seçilirken, t.y.)

\section{Kaynakça}

Abisel, N. (1999). Popüler Sinema ve Film Türleri (2. bs). Alan Yayıncılık.

Adair, G. (1993). Postmodernci kapıyı iki kere çalar = The postmodernist always rings twice (N. Dikbaş, Çev.). İletişim.

Alangu, T. (2016). Keloğlan Masalları. Yapı Kredi Yayınları.

Aragay, M., \& Lopez, G. (2005). Inf(l)ecting Pride and Prejudice: Dialogism, Intertextuality, and Adaptation. Içinde M. Aragay (Ed.), Books in Motion Adaptation, Intertextuality. Rodopi.

Aykın, C. (1983). Batı Toplumlarında Roman ve Sinema İlişkileri. Türk Dili, 383, 482-503.

Bacchilega, C. (1997). Postmodern fairy tales: Gender and narrative strategies. Philadelphia : University of Pennsylvania Press. https://trove.nla.gov.au/version/45603908

Barut, Ö. (2007). Türk Sineması'nda Anlatım Tarzlarına Göre Edebiyat Uyarlamaları [Yüksek Lisans]. Gazi Üniversitesi.

Bazin, A. (1995). Çağdaş Sinemanın Sorunları (N. Özön, Çev.; 2.). Bilgi.

Bettelheim, B. (2010). The Uses of Enchantment The Meaning and Importance of Fairy Tales. Vintage.

Bilgiç, F. (2002). Türk sinemasında 1980 sonrası üslup arayışları (1. baskı). T.C. Kültür Bakanlığl.

Blues Perişan: 1970'de "7 Cüceler" seçilirken. (t.y.). Geliş tarihi 23 Nisan 2020, gönderen https://bluesperisan.blogspot.com/2014/10/1970de-7-cuceler-secilirken.html

Bourdieu, P. (2006). Sanatın kuralları yazınsal alanın oluşumu ve yapısı (N. K. Selvi, Çev.). YKY.

Cansız, A. B. (2011). Edebiyat Eserlerinden Romanın Sinema ve Televizyona Uyarlanması ve Değișen Anlatım Dili. RTÜK. 
Çakır, S. (2017). Yeşilçam Sineması ve Masal Formu: Ayşecik. Turkish Studies, 12(21), 133150.

Çetin-Erus, Z. (2005). Amerikan ve Türk sinemalarında uyarlamalar: Karşılaştırmalı bir bakış. Es Yayınları.

Çocuk ve Yuva Masalları Kitabının Görseli. (2020, Mayıs 17). https://merseburger. de/. https://merseburger.de/produkt/kinder-und-hausmaerchen-fuer-daspianoforte-2/

Desmond, J. M., \& Hawkes, P. (2006). Adaptation: Studying Film and Literature. McGrawHill.

Disney'in 1937'deki Pamuk Prenses ve Yedi Cüceler film afişi. (2020, Mayıs 17). www.ebay. com. (https://www.ebay.com/itm/SNOW-WHITE-AND-THE-7-SEVEN-DWARFS1937-CineMasterpieces-MOVIE-POSTER-DISNEY-/171888986890)

Doğan, E. (2018). Türk Sineması'nda Masal Uyarlamaları ve Vladimir Propp'un Halk Masalları İşlevlerinin Pamuk Prenses ve Yedi Cüceler Filminde Çözümlenmesi. Turkish Studies, 13(23), 53-63.

Dundes, A. (2006). Fakelore Fabrikasyonu (A. Uçar, Çev.). Millî Folklor, 18(70), 92-101.

Ertem Göreç. (t.y.). www.kameraarkisi.org. Geliş tarihi 23 Nisan 2020, gönderen http:// www.kameraarkasi.org/yonetmenler/ertemgorec.html

Ewîg, U. (1990). Masal, Masal Araștırması ve Masal Derlemesi Üzerine (Z. C. Arda, Çev.). Millî Folklor, 6, 2-10.

Filmde oynayan Yedi Cüceler. (2020, Mayıs 17). https://bluesperisan.blogspot. com/2014/10/1970de-7-cuceler-secilirken.html. https://bluesperisan.blogspot. com/2014/10/1970de-7-cuceler-secilirken.html

Frome, J. (2013). Snow White: Critics and Criteria for the Animated Feature Film. Quarterly Review of Film and Video., 30, 462-473.

Göreç, E. (1970). Pamuk Prenses ve Yedi Cüceler [Fantastik, Duygusal, Aile]. Hisar Film.

Göreç, E. (2018, Subat). Pamuk Prenses ve Yedi Cüceler. Ertem Göreç’le Söyleşi [İstanbul Kartal Sanatçı Yaşam Evi].

Inge, M. T. (2004). Walt Disney's Snow White Art, Adaptation and Ideology. Journal of Popular Film and Television., 32(3), 132-142.

Kaminski, W. (2016). Çocuk ve Gençlik Edebiyatına Giriş (Y. Baş, Çev.; 2.). Milli Eğitim Bakanlığl.

Köse, H. (2014). Skolastik Fantazya. Ayrıntı.

Kristeva, J. (1980). Desire in language: A semiotic approach to literature and art. Columbia University Press.

Moen, K. (2013). Film and Fairy Tales: The Birth of Modern Fantasy. I.B. Tauris.

Monaco, J. (2011). Bir Film Nasıl Okunur? (E. Yılmaz, Çev.). Oğlak Yayıncılık.

Ölçer Özünel, E. (2011). Yazının İzinde Masal Haritalarını Okuma Denemesi: Masal Tarihine Yeniden Bakmak. Millî Folklor, 23(91), 60-71. 
Özcan Dost, B., \& Taștan, T. E. (2017). Metinlerarasılık Bağlamında Bir İnceleme: Pamuk Prenses ve Yedi Cüceler ile Pamuk Prenses ve A. International Journal of Languages' Education, 1, 124-131. https://doi.org/10.18298/ijlet.1745

Özsel, K. T. (2017). Walt Disney Animasyon Sinemasında Kadın Temsilleri 2010 Öncesi ve Sonrası. LAP LAMBERT Academic Publishing.

Pallant, C. (2010). Disney-Formalism: Rethinking 'Classic Disney'. Animation, 5(3), 341352. https://doi.org/10.1177/1746847710377567

Pamuk Prenses ve Yedi Cüceler Film Afişi ve Filmden çeşitli sahneler. (2020, Mayıs 17). www. tsa.org.tr. https://www.tsa.org.tr/tr/film/filmgoster/1306/pamuk-prenses-veyedi-cuceler

Propp, V. I. (2017). Masalın Biçimbilimi ve Olağanüstü Masalların Dönüşümleri (S. Rifat \& M. Rifat, Çev.; 3. bs). İş Bankası Kültür.

Sarı, A., \& Ercan, C. A. (2008). Masalların psikanalizi (1. basım). Salkımsöğüt Yayınları.

Scognamillo, G., \& Demirhan, M. (1999). Fantastik Türk Sineması. Kabalcı.

Stam, R. (2000). Beyond Fidelity: The Dialogics of Adaptation. Içinde J. Naremore (Ed.), Film Adaptation (ss. 54-78). Rutgers University Press.

Stringham, E. (2011). Disney and the butchering of Snow White. Economics, Management, and Financial Markets, 6(2), 637-653.

Şakrak, B. E. (2017). Film Uyarlamalarında Anlatının Dönüşümü Yetişkinlere Masallar: Pamuk Prenses. Içinde N. Bilici, R. Pehlivanlı, \& S. Demirkılınç (Ed.), Innovation and Global Issues In social Sciences extended Abstract Book (s. 649655). Inglobe.

Şasa, A. (2002). Yeşilçam Günlüğü. Dergah.

Şeşen, E. (2008). Büyüklere Masallar: Fantastik Filmler ve Gündelik Yaşamda Büyünün Yeniden Keşfi. İletişim Kuram ve Araştırma Dergisi, 27, 77-98.

Tek oyuncunun iki karaktere bürünmesi. (2020, Mayıs 17). www.sinematikyesilcam.com. https://sinematikyesilcam.com/2013/12/fantastik-turk-sinemasi-galeri-004/

Tuğan, N. H. (2017). A ̆g Anlatının Yükselişi: Son Dönem Hollywood Ve Türk Sinemasında Farklı Anlatı Biçimleri. Gümüşhane Üniversitesi İletişim Fakültesi Elektronik Dergisi, 5(2), 1024-1044. https://doi.org/10.19145/e-gifder.288364

Tunalı, D. (2017). Popüler Masallardan Sinemaya Yapılan Uyarlamalarda Kültürel Antropolojik Süreklilik ve Dönüșüm. Journal of International Social Research, 10(49), 362-372. https://doi.org/10.17719/jisr.2017.1587

Tunç, E. (2012). Türk Sinemasının Ekonomik Yapısı (1896-2005). Doruk Yayınları.

Wasko, J. (2007). Understanding Disney: The Manufacture of Fantasy (1 edition). Polity.

Yedi Cüceler Çankaya Köşkünde. (t.y.). www.turknostalji.com. http://www.turknostalji. com/yedi-cuceler-cankaya-koskunde.html.

Yılmaz, B. H. (2013). Masalların Dönüşü Masalların Dönüşümü: Çağdaş Türk Edebiyatında Grimm Masallarının Metinlerarası Kullanımları (Murathan Mungan Örneği) [Yüksek Lisans]. Osmangazi Üniversitesi. 
Zipes, J. (1975). Breaking the Magic Spell: Politics and the Fairy Tale. New German Critique, 6, 116-135. JSTOR. https://doi.org/10.2307/487657

Zipes, J. (2006). Fairy Tales and the Art of Subversion: The Classical Genre for Children and the Process of Civilization (2. bs). Routledge. 


\title{
Three Forms of the (Fair Tale of) "Snow White and the Seven Dwarfs": Brothers Grimm, Walt Disney and Ertem Göreç
}

\author{
Zeynep Gültekin Akçay (Asst. Prof. Dr.)
}

\section{Extended Abstract}

Oral narratives, which are social outputs, have been reproduced during the transfers since their first release and have survived to this day. Tales in the oral tradition have become sources and materials for new narratives. They are reproduced when fairy tales are the source of every new narrative. In this reproduction process, fairy tales have survived in two forms: oral tradition and written tradition. One of these is the oral fairy tale tradition that lives naively in the public; the other is the written tradition, the traces of which can be seen today, which attract the attention of the literate segment. In the process of writing the tale, giving oral expressions to shape as desired was essentially a threshold for the transition from collective creation to individual design. Any element added to the folk tale from a particular person's pen and the signature put under the tale made it a creation of a single person, rather than being the production of the public. When fairy tales became a part of written literature, they now gained the name of a writer whose borders were drawn, writing themselves, and acquired a target audience. Tales have been transformed into successive products in a sense by changing their target audiences, languages, contents and formats, thus, they have managed to survive on a global scale until today.

Snow White and the Seven Dwarfs also made historical and global progress in line with this recipe. The tale was first conveyed from the word to the text by German Grimm Brothers, during this period the Grimm Brothers intervened in the text. When Snow White and the Seven Dwarfs were adapted to the cartoon film by Walt Disney in 1937, they were once again subjected to changes brought by reproduction. The tale was adapted to Yeşilçam by Ertem Göreç in 1970 and became a text containing the cultural and aesthetic tastes of the Turkish cinema audience.

The subject of this study is the different reproduction forms of Snow White and Seven Dwarfs in different periods. Grimm Brothers (1812), who wrote the tale in writing, Walt Disney (1937), who adapted Grimmler's tale to the animation, and Ertem Göreç (1970), who adapted the animation of Walt Disney to the film, formed the sample of the study. It seems that there is a wide variety of changes in the reproduction of fairy tales, from the number of heroes, to space and time fiction, to the plot. It is the main problem of the study to reveal what these differences are and the basic elements of the reasons of the differences. In this process, the debates put forward by Jack Zipes for fairy tales were adopted in the study and his basic arguments were taken. The transfer, execution, distribution and consumption stages of the literary works and their cultural and economic dimension were not duly emphasized. This situation causes a serious deficiency in the discipline. There is a similar process in the field of cinema: literary works such as theater, cinema, etc. The creativity values of the films were studied by evaluating them as a source for the texts, folklore, etc. associations with different disciplines are not very preferred. While the creation value of the text is discussed in terms of the discipline of literature in studies related to the Snow White and the Seven Dwarfs tale, studies on Walt Disney's Snow White and the Seven Dwarfs were mostly shaped by addressing its formal adaptation differences. The Snow White in Yeşilçam was discussed as the first film 
that led to the beginning of the fairy tale popularity, and the free adaptations of the fairy tale were studied; however, it has not been considered as a cartoon adaptation of Disney and has not been studied in detail. At this point, the study hopes to be able to leave the researches mentioned above and contribute to the understanding of the reproduction process of the tale by associating the differences in the forms of reproduction of the tale with the adaptation of written works, cartoons and movies.

As a result, the brothers Wilhem and Jacob changed the fairy tale in writing in 1812 and adapted it to the social conditions of the period. It is possible to say that they made the adaptation very consciously. In Grimm Brothers, Snow White and the Seven Dwarfs, they put the dominant bourgeois ideology of the period into tales by defining women in households, men in public life, and Christian doctrines in everyday life. In this way, the fairy tales was removed from the ordinary person who created the oral folk tradition and the fairy tale was tame.

In 1937, Walt Disney adapted the story of Grimm Brothers to the animation in order to improve the mood of the American people who tries to deal with the 1929's economic crisis and to dedicate some of his budget to the cinema. While making the adaptation, Disney made changes in the fairy tale, taking the American audience's practices of watching movies. While making reductions in the story of the tale, he also changes the weight of his heroes in the tale. To make the audience stay in the movie theather for eighty minutes, he eliminated the heavy Christian doctrines of the tale and added comedy elements instead. The emphasis on the most decisive change in the fairy tale was the American ideology. Accordingly, values such as work ethics, patriotism, individualism, capitalism, holiness of the family institution, unequal sharing of social power have been placed on the fairy tales and changed to a different structure from the Grimm narrative. In 1970, Ertem Göreç adapted Disney's cartoon to the movie in order to bring a new breath to Yeşilçam cinema, which is experiencing economic difficulties such as Disney, and to bring the audience back to the theaters. With the effect of commercial concerns in Yeşilçam cinema of the period, Göreç tried to adhere to Disney narration as an innovation to melodrama, laugh and fantasy, and could not ignore the tastes and expectations of the Turkish cinema audience.

Keywords: Snow White and the Seven Dwarfs Movie, Grimm Brothers' Fairy, Walt Disney Animation, Ertem Göreç. 